J Am Chem Soc. 2016 November 02; 138(43): 14488-14496. doi:10.1021/jacs.6b09504.

\title{
Metal Organic Polyhedron Capped with Cucurbit[8]uril Delivers Doxorubicin to Cancer Cells
}

\author{
Soumen K. Samanta ${ }^{a}$, Damien Moncelet ${ }^{b}$, Volker Briken ${ }^{b,}$, , and Lyle Isaacs ${ }^{a},{ }^{*}$ \\ aDepartment of Chemistry and Biochemistry, University of Maryland, College Park, MD 20742 \\ (USA) \\ bDepartment of Cell Biology and Molecular Genetics, University of Maryland, College Park, MD \\ 20742 (USA)
}

\begin{abstract}
Self-assembly of ligand $\mathbf{1}$ and $\mathrm{Pd}\left(\mathrm{NO}_{3}\right)_{2}$ delivers Fujita-type metal organic polyhedron (MOP) $\mathbf{3}$ which bears 24 covalently attached methyl viologen units on its external surface as evidenced by ${ }^{1} \mathrm{H}$ NMR, DOSY NMR, electrospray mass spectrometry, TEM, and AFM measurements. MOP 3 undergoes non-covalent complexation with cucurbit[n]urils to yield MOPs $4-6$ with diameter $\approx$ 5-6 $\mathrm{nm}$. MOP 5 can be fully loaded with doxorubicin prodrug $\mathbf{2}$ via hetero ternary complex formation to yield 7 . The MOPs exhibit excellent stability toward neutral to slightly acidic $\mathrm{pH}$ in $10 \mathrm{mM}$ sodium phosphate buffer mitigating the concern of disassembly during circulation. The results of MTS assays show that MOP 7 is 10-fold more cytotoxic toward HeLa cells than equimolar quantities of doxorubicin prodrug 2 . The enhanced cytotoxicity can be traced to a combination of enhanced cellular uptake of $\mathbf{7}$ and DOX release as demonstrated by flow cytometry and confocal fluorescence microscopy. The confluence of properties imparted by the polycationic MOP architecture and plug-and-play $\mathrm{CB}[\mathrm{n}]$ complexation provides a potent new platform for drug delivery application.
\end{abstract}

\section{Graphical abstract}

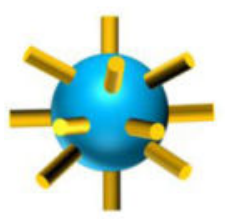

$\left[\mathrm{Pd}_{12} \mathbf{1}_{24} 4^{12^{2 *}}\right.$

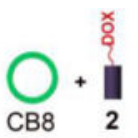

in $\mathrm{D}_{2} \mathrm{O}$

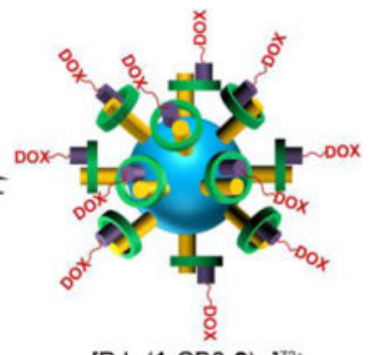

$\left[\mathrm{Pd}_{12}(1 \cdot \mathrm{CB} 8 \cdot 2)_{24}\right]^{72 *}$

*Corresponding Author: LIsaacs@umd.edu, vbriken@umd.edu.

Supporting Information. Experimental procedures, ${ }^{1} \mathrm{H}$ NMR, ${ }^{13} \mathrm{C}$ NMR, DOSY, ESI-Ms, UV/Vis, Fluorescence, TEM, AFM image, zeta potential measurement, in vitro study, molecular modelling. 


\section{Introduction}

A major thrust in chemistry, biology, and medicine in the past two decades has been the development of new drug delivery systems that improve drug efficacy and decrease side effects by controlling their pharmacokinetic and biodistribution profiles. ${ }^{1,2}$ Accordingly, various drug delivery systems such as protein-drug conjugates, polymer-drug conjugates, polymersomes, nanomicelles, dendrimers, polymeric nanoparticles, and noble metal nanoparticles have been explored for cancer therapy and imaging. ${ }^{3,4,5}$ Some of these drug delivery systems take advantage of the enhanced permeability and retention (EPR) effect whereas others incorporate targeting ligands. ${ }^{2,6}$ Despite these advances, the clinical application of some first-line chemotherapy drugs like doxorubicin is limited by significant cardiotoxicity and rapid clearance. ${ }^{7,8}$ One strategy to reduce toxicity toward normal cells is the development of prodrugs whose cytotoxicity is activated only in a tumor microenvironment (e.g. cathepsin B expression, acidic cytosol). ${ }^{3,9}$ Unfortunately, some doxorubicin prodrugs undergo sluggish cellular internalization which hampers their efficacy. ${ }^{10}$ In this paper, we seek to combine the desirable structural properties of a nanoscale metal-organic polyhedron scaffold with those of a doxorubicin prodrug (2) selfassembled via host-guest assistance with cucurbit[8]uril.

In recent years, supramolecular chemists have used self-assembly processes to prepare functional self-assembled architectures of nanoscale dimensions driven by metal-ligand coordination interactions. ${ }^{11,12,13}$ The integration of metal-ligand coordination assemblies with biological systems, particularly for drug delivery and diagnosis, is substantially less developed. ${ }^{12,14-16}$ Previously, Stang, Chi, Therrien and others have reported the anticancer activity of supramolecular coordination complexes. ${ }^{17}$ The use of supramolecular coordination cages as anticancer drug delivery vehicles was first reported by Therrien. ${ }^{15,18}$ Recently, Lippard reported a well-defined supramolecular system (a Pt(II) metallacycle) as a drug delivery vehicle to deliver a Pt(II) prodrug to cancer cells. ${ }^{14}$ It is known that particle size influences the clearance rate of nanoparticles from the bloodstream, therefore compared to smaller sized coordination complexes studied previously ( $\leq 1.5 \mathrm{~nm}$ ), we believe the larger sized supramolecular structures $(\approx 5-6 \mathrm{~nm}$ ) studied here should display slower renal clearance and longer circulation which would be useful for theranostic applications and enhanced tumor uptake by the EPR effect. ${ }^{5,8}$ Previously, the Fujita group has developed powerful strategies to synthesize large roughly spherical assemblies including cubooctahedral nanocages $\left(\operatorname{Pd}_{12} \mathbf{L}_{24}\right.$ composition) by mixing $\mathrm{Pd}^{2+}$ and an angular bispyridine ligand (L). ${ }^{19,20}$ An attractive aspect of this system is the capability of exohedral or endohedral cage functionalization via ligand $(\mathbf{L})$ functionalization. ${ }^{13}$ We envisioned that these large spherical assemblies, when appropriately functionalized, would prove complementary to and thereby enrich the toolbox of nanoparticle based drug delivery vehicles. $^{5,8,21,22,23}$

Specifically, we sought to marry the geometrical features of metal organic polyhedra (MOP) with the outstanding recognition properties of the cucurbit[n]uril family which have unfolded rapidly over the past decade. ${ }^{24,25,26}$ For example, CB[n] compounds exhibit ultratight binding affinity and high selectivity toward cationic guests in water and do so in a stimuli responsive (e.g. pH, chemical, photochemical, electrochemical) manner. ${ }^{27,28}$ 
Furthermore, the elegant work of Kim, Scherman, and others show that larger $\mathrm{CB}[\mathrm{n}]$ hosts (especially CB[8]) display the ability to form homo and hetero ternary (e.g. host•guest•guest) complexes whereby a cationic first guest (e.g. methyl viologen (MV), Chart 1) promotes the binding of a neutral second guest. ${ }^{26,27,29,30}$ These CB[8] controlled systems have been used to advantage in the preparation of supramolecular polymeric systems for biological and materials applications, chemical sensing ensembles, molecular machines, non-covalent promotors of biological dimerization, and supramolecular catalysis. ${ }^{27,31,32}$ Given their excellent biocompatibility, other recent efforts have sought to use $\mathrm{CB}[\mathrm{n}]$-type receptors to enhance drug solubility, for imaging applications, and as a drug reversal agent. ${ }^{31,33}$ Pioneering work in this area was performed by Yang, Zink, and Stoddart based on mesoporous silica nanoparticles that are gated by host•guest recognition processes. ${ }^{23,34}$ In this paper, we decorate the external surface of Fujita-type $\operatorname{Pd}_{12} \mathbf{L}_{24}$ metal organic polyhedra (MOP) with MV ligands, explore their non-covalent functionalization with $\mathrm{CB}[\mathrm{n}]$, and demonstrate their ability to deliver doxorubicin to cancer cells.

\section{Results and Discussion}

\section{Synthesis of Ligand (1) and Complexation with CB[n]}

The synthesis of MOPs studded with MV units required the synthesis of ligand 1 (Scheme 1). First, methyl bipyridinium iodide was reacted with ethyl-4-bromobutyrate to afford compound $\mathbf{8}$ which was hydrolyzed using aqueous $\mathrm{HBr}$ to give $\mathbf{9}$. Suzuki coupling between 3,5-dibromoaniline and pyridine-4-boronic acid gave 10. Carbodiimide promoted amide bond formation between $\mathbf{9}$ and $\mathbf{1 0}$ gave $\mathbf{1}$ in $\mathbf{7 8 \%}$ yield. The spectroscopic characterization of all new compounds is given in the Supporting Information.

To determine whether $\mathrm{CB}[\mathrm{n}]$ complexation with $\mathbf{1}$ might interfere with MOP formation or stability, we first studied the complexation with $\mathrm{CB}$ [7] and $\mathrm{CB}$ [8]. Diagnostic upfield shifting for $\mathrm{H}_{\mathrm{f}}$ and $\mathrm{H}_{\mathrm{g}}$ of ligand $\mathbf{1}$ when bound to $\mathrm{CB}$ [7] or $\mathrm{CB}[8]$ (SI, Figure S35 and S36) indicate that the methyl viologen subunit of $\mathbf{1}$ is the dominant binding site for $\mathrm{CB}$ [7] and $\mathrm{CB}[8]{ }^{25,35,36} \mathrm{CB}[8] \cdot \mathbf{1}$ also maintains its ability to form the ternary charge-transfer complex $\mathrm{CB}[8] \cdot \mathbf{1} \cdot \mathrm{HN}$ as evidenced by UV/Vis spectroscopy and complexation induced changes in chemical shift (SI, Figure S36 and S46)..$^{35}$

\section{Synthesis and Characterization of MOP 3}

Next, we synthesized metal organic polyhedron $\mathbf{3}=\left[\mathrm{Pd}_{12} \mathbf{1}_{24}\right]\left(\mathrm{NO}_{3}\right)_{72}$, by heating a mixture of 1 and $\mathrm{Pd}\left(\mathrm{NO}_{3}\right)_{2} \cdot 2 \mathrm{H}_{2} \mathrm{O}$ (0.5 equiv.) at $60{ }^{\circ} \mathrm{C}$ in DMSO- $d_{6}$ for $24 \mathrm{~h}$ (Figure 1a). MOP 3 was characterized by ${ }^{1} \mathrm{H}$ NMR, diffusion-ordered spectroscopy (DOSY) and cold-spray ionization mass spectroscopy (CSI-MS). For example, the ${ }^{1} \mathrm{H}$ NMR spectra (Figure 1b,c) shows the typical downfield shifting of pyridine protons $\left(\mathrm{H}_{\mathrm{a}}\right.$ and $\left.\mathrm{H}_{\mathrm{b}}\right)$ upon formation of $\mathbf{3}$ $\left(\mathrm{H}_{\mathrm{a}}: 8.69\right.$ to $9.42 \mathrm{ppm} ; \mathrm{H}_{\mathrm{b}}: 7.72$ to $\left.8.23 \mathrm{ppm}\right) .{ }^{19}$ The broadening of the bis(pyridine) resonances $\left(\mathrm{H}_{\mathrm{a}}-\mathrm{H}_{\mathrm{d}}\right)$ reflect their slower tumbling motion with respect to the methyl viologen units of 3. DOSY NMR (Figure 1d,e) was used to measure the diffusion coefficients for $\mathbf{3}\left(\mathrm{D}=3.55 \times 10^{-11} \mathrm{~m}^{2} / \mathrm{s}\right)$ and $\mathbf{1}\left(\mathrm{D}=3.20 \times 10^{-10} \mathrm{~m}^{2} / \mathrm{s}\right)$. The slower diffusion of $\mathbf{3}$ reflects its larger diameter which can be calculated using the Stokes-Einstein equation as $6.2 \mathrm{~nm}$ which agrees with the MMFF optimized structure of $\mathbf{3}$ (SI, Figure S61 \& 
Table S1). CSI-MS provided further structural evidence of $\mathbf{3}$ following anion exchange from nitrate $\left(\mathrm{NO}_{3}{ }^{-}\right)$to triflate $\left(\mathrm{OTf}^{-}\right)$via observation of a series of prominent ions $[\mathrm{M}-x(\mathrm{OTf})$ $+y \mathrm{DMSO}]^{x+}(x=15-40)$ which can be traced to the parent ion of $\mathbf{3}=\left[\mathrm{Pd}_{12} \mathbf{1}_{24}\right](\mathrm{OTf})_{72}(\mathrm{SI}$, Figure S23) with molecular weight of $17443.56 \mathrm{amu}$. MOP 3 is highly cationic (72+) due to its twelve $\mathrm{Pd}^{2+}$ ions and 24 pendant methyl viologen units which promote aqueous solubility. Accordingly, a DMSO- $d_{6}$ solution of 3 was dialyzed against $\mathrm{D}_{2} \mathrm{O}(\mathrm{MWCO}=$ 3500 ) for $24 \mathrm{~h}$ to afford an aqueous solution of $\mathbf{3}$. MOP 3 can be isolated in solid form by removal of DMSO under high vacuum or by addition of EtOAc to the DMSO solution. The ${ }^{1} \mathrm{H}$ and DOSY spectra (SI, Figure S25 \& S27) recorded for MOP 3 in $\mathrm{D}_{2} \mathrm{O}$ are analogous to those measured in DMSO which establishes both the size $(6.2 \mathrm{~nm})$ and stability of $\mathbf{3}$ in water.

\section{Capping of MOP 3 with $\mathrm{CB}[\mathrm{n}]$}

After having firmly established the structure of $\mathbf{3}$ we turned to an investigation of its supramolecular chemistry with $\mathrm{CB}[\mathrm{n}](\mathrm{n}=7,8)$. Treatment of MOP 3 with $\mathrm{CB}$ [7] (24 equiv.) in $\mathrm{D}_{2} \mathrm{O}$ resulted in significant ${ }^{1} \mathrm{H}$ NMR upfield shifts for $\mathrm{H}_{\mathrm{f}}$ and $\mathrm{H}_{\mathrm{g}}(8.45 \& 8.33$ to $6.99 \mathrm{ppm}$ ) of the pendant methyl viologen units which reflects their inclusion in the anisotropic shielding region of $\mathrm{CB}$ [7] (Figure 2a,b). ${ }^{36}$ Figure 1a shows a molecular model of MOP $4=\left[\operatorname{Pd}_{12}(\mathbf{1} \cdot \mathrm{CB} 7)_{24}\right]\left(\mathrm{NO}_{3}\right)_{72}$. The DOSY NMR for 4 (Figure 2e) clearly shows a single band at $\mathrm{D}=9.55 \times 10^{-11} \mathrm{~m}^{2} / \mathrm{s}$; in contrast free $\mathrm{CB}[7]$ diffuses much faster $(\mathrm{D}=5.0 \times$ $10^{-10} \mathrm{~m}^{2} / \mathrm{s}$, SI Figure S30) which indicates that the $\mathrm{CB}$ [7] molecules are bound to the $\mathbf{M V}$ units studding the nanosphere. The UV/Vis titration of $\mathbf{3}(2.0 \mu \mathrm{M})$ with $\mathrm{CB} 7(0-30 \mu \mathrm{M})$ shows a decrease in absorbance at $274 \mathrm{~nm}$ which is diagnostic for CB7•MV complexation (SI, Figure S45). The plot of absorbance versus CB[7] concentration could be fitted to a 1:1 binding model $\left(K_{a}=(1.6 \pm 0.7) \times 10^{6} \mathrm{M}^{-1}\right)$ assuming all 24 binding events are independent. The plot shows a plateau at a MOP 3:CB[7] stoichiometry of 1:24 which allowed us to calculate that $>90 \%$ of $\mathrm{CB}[7]$ is bound to MOP 3 under these conditions. Remarkably, a comparison of the DOSY spectra of $\mathbf{3}$ and $\mathbf{4}$ (Figure 2d,e) indicates that the complexation of $24 \mathrm{MV}$ units by $\mathrm{CB}$ [7] does not increase the hydrodynamic diameter of MOP 4 (5.2 nm) even though molecular weight increases by $27911 \mathrm{amu}$ ! In contrast, the diameter of MOP 4 $(\mathrm{d}=5.2 \mathrm{~nm})$ decreases by $\approx 1.0 \mathrm{~nm}$ compared to MOP $3(\mathrm{~d}=6.2 \mathrm{~nm})$ as evidenced by DOSY NMR (SI, Table S1). We attribute this smaller diameter to hydrophobic interactions between the outer surface of CB7 and the aromatic scaffold of the MOP.

Despite numerous attempts we were unable to grow single crystals of sphere 4. However, we were successful in visualizing MOP 4 by transmission electron microscopy (TEM) which revealed both the size (4-5 $\mathrm{nm}$ diameter) and spherical shape of individual MOPs upon deposition of aqueous solution of $\mathbf{4}$ on carbon coated $\mathrm{Cu}$ grids (SI, Figure S55). Furthermore, we obtained atomic force microscopy (AFM) images of $\mathbf{4}$ deposited on a freshly cleaved mica surface which showed particles with a height of 5-6 $\mathrm{nm}$ above the surface, consistent with the anticipated diameter (SI, Figure S59). The non-covalent CB[7] caps on the MV studded surface of $\mathbf{4}$ can be reversed in a stimuli responsive fashion ${ }^{26,27}$ by the addition of adamantane ammonium (ADA) to regenerate 3 along with the ultratight CB[7]•ADA complex (Figure 2c). 
In a similar manner, we capped the MV studs of $\mathbf{3}$ with $\mathrm{CB}[8]$ to afford MOP $\mathbf{5}=$ $\left[\mathrm{Pd}_{12}(\mathbf{1} \cdot \mathrm{CB} 8)_{24}\right]\left(\mathrm{NO}_{3}\right)_{72}$ (Figure 3a). As expected, the $\mathrm{H}_{\mathrm{f}}$ and $\mathrm{H}_{\mathrm{g}}$ protons exhibit an upfield shift $\left(\Delta \delta \approx 0.7 \mathrm{ppm}\right.$ ) upon complexation with $\mathrm{CB}[8]$ (Figure 3b,c) whereas $\mathrm{H}_{\mathrm{i}}$ which is located near the deshielding ureidyl $\mathrm{C}=\mathrm{O}$ portals moves slightly downfield. DOSY NMR establishes that the MOP and $\mathrm{CB}[8]$ units in 5 diffuse at the same rate $\left(\mathrm{D}=8.91 \times 10^{-11}\right.$ $\left.\mathrm{m}^{2} / \mathrm{s}\right)$ which is much slower than free CB[8] $\left(\mathrm{D}=3.16 \times 10^{-10} \mathrm{~m}^{2} / \mathrm{s}\right.$, SI Figure S34) indicating that the $\mathrm{CB}[8]$ molecules are non-covalently attached to nanosphere 3 . We visualized 5 by both TEM and AFM microscopy. TEM images (Figure 4a) show the spherical shape of the particles with an average diameter of $5.2 \mathrm{~nm}$ (SI, Figure S56). The particle height observed by AFM images of $5(\approx 5.5 \mathrm{~nm}$, Figure $4 \mathrm{~b})$ is consistent with the MMFF minimized diameter of 5 (SI, Figure S63).

\section{Hetero ternary complexation with MOP 5}

Given the ability of CB8 $\bullet \mathbf{M V}$ to form hetero ternary complexes with various second guest molecules, ${ }^{26,27,29,35}$ we envisioned that $\mathbf{5}$ would be useful for the complexation of payloads on its $\mathrm{CB}[8]$ studded surface. As proof-of-principle we choose the well known second guest 2,6-dihydroxynaphthalene (HN). Accordingly, we monitored the addition of $\mathbf{H N}$ (24 equiv.) to an aqueous solution of 5 by both ${ }^{1} \mathrm{H}$ NMR and UV/Vis spectroscopy (Figure $3 \mathrm{~d}$ and $4 \mathrm{c}$ ) which yields MOP $\mathbf{6}=\left[\mathrm{Pd}_{12}(\mathbf{1} \bullet \mathrm{CB} 8 \cdot \mathbf{H N})_{24}\right]\left(\mathrm{NO}_{3}\right)_{72}$ (Figure 3a). As expected based on literature precedent, protons $\mathrm{H}_{\mathrm{f}}$ and $\mathrm{H}_{\mathrm{g}}$ of methyl viologen unit and the $\mathbf{H N}$ protons undergo further upfield shifting (to 6.94 and $6.74 \mathrm{ppm}$ ) upon hetero ternary complex formation of MOP $6 .{ }^{35}$ The formation of 6 is based on charge transfer interactions and accordingly, UV/Vis titration of $\mathbf{5}(20 \mu \mathrm{M})$ with $\mathbf{H N}(0-500 \mu \mathrm{M})$ displays a long wavelength absorbance at $570 \mathrm{~nm}$ that is diagnostic for the hetero-ternary complexation (Figure $4 \mathrm{c}$ ).

\section{Design, Synthesis, and pH-Responsive Behavior of Prodrug 2}

The ability of MOP $\mathbf{5}$ to form hetero-ternary complexes suggested its use as a scaffold for the delivery of anticancer drugs. We expected that both the size and high charge of $\mathbf{5}$ would influence the cellular uptake and trafficking in vitro and perhaps exhibit the EPR effect when used in vivo and show enhanced biodistribution and pharmacokinetics. ${ }^{14,37}$ For this purpose we initially explored the complexation of the potent anticancer drug Doxorubicin (DOX) with 5 but did not observe ternary complex formation by ${ }^{1} \mathrm{H}$ NMR spectroscopy (Figure S38). As an alternative to a direct complexation strategy, we designed doxorubicin prodrug 2 which features a 2-alkoxynaphthalene substituent covalently connected to DOX. Such 2alkoxynaphthalenes are known to form strong ternary complexes $\left(K_{\mathrm{a}}=10^{5} \mathrm{M}^{-1}\right)$ with $\mathrm{CB}[8] \bullet \mathbf{M V} .{ }^{29}$ Accordingly, we synthesized $\mathbf{2}$ in four steps as shown in Scheme 1. First, 2hydroxynaphthalene was reacted with ethyl-5-bromovalerate to give $\mathbf{1 1}$ which was hydrolyzed by LiOH to give 12. Next, carboxylic acid $\mathbf{1 2}$ was transformed into acyl hydrazine 13. Lastly, $\mathbf{1 3}$ and DOX were treated to give acyl hydrazone doxorubicin prodrug 2.

To minimize side effects and exhibit maximum therapeutic efficacy, it is imperative that 2 releases DOX after internalization by cancer cells. The design of $\mathbf{2}$ capitalized on the more acidic environment of cancer cells and the acid labile nature of the hydrazone bond of $\mathbf{2}$. The $\mathrm{UV} / \mathrm{Vis}$ spectrum of $\mathbf{2}$ is quite similar to free DOX but the fluorescence emission of $\mathbf{2}$ is 
reduced 2.6-fold relative to DOX (SI, Figures S47 and S48). ${ }^{38}$ To test the $\mathrm{pH}$ responsiveness, $2(20 \mu \mathrm{M})$ was incubated in $10 \mathrm{mM}$ sodium phosphate buffer at $\mathrm{pH} 7.4$ and $10 \mathrm{mM}$ sodium acetate buffer at $\mathrm{pH}$ 6.5, $5.5 \& 4.0$ and the fluorescence emission spectra was measured for 5 h (SI, Figures S51 - S54). Figure 4d shows a plot of fluorescence emission intensity at $597 \mathrm{~nm}$ as a function of incubation time and pH. At pH 7.4 no release of DOX was observed after $5 \mathrm{~h}$ whereas $55 \%$ and $80 \%$ of DOX were released at $\mathrm{pH} 6.5$ and 5.5 , respectively. At pH 4.0, >90\% of DOX was released from 2 within 3 h establishing the $\mathrm{pH}$ responsiveness of $\mathbf{2}$ at endo- and lysosomal $\mathrm{pH}$ of cancer cells. In this manner, $\mathbf{2}$ is expected to deter release of DOX during circulation and promote its release only after cellular uptake which should enhance its efficacy.

\section{Loading MOP 5 with Prodrug 2}

Next, we decided to load MOP 5 with DOX as cargo in the form of prodrug 2 (inherent $\mathrm{D}_{2} \mathrm{O}$ solubility $(830 \mu \mathrm{M})$. Accordingly, 5 was treated with 24 equiv. of 2 in $\mathrm{D}_{2} \mathrm{O}$ to give MOP $7=$ $\left[\mathrm{Pd}_{12}(\mathbf{1} \bullet \mathrm{CB} 8 \cdot \mathbf{2})_{24}\right]\left(\mathrm{NO}_{3}\right)_{72} \cdot{ }^{1} \mathrm{H} \mathrm{NMR}$ shows that the naphthalene protons of $\mathbf{2}$ undergo upfield shift (Figure 3e) to $6.72 \mathrm{ppm}$ (similar to that observed for [CB8・MV•2], SI Figure S39) which reflects the binding of $\mathbf{2}$ to $\mathbf{5}$ based on CB8 $\cdot \mathbf{M V} \cdot \mathbf{H N}$ type hetero ternary complexation as shown in Figure 3a. The presence of a strong UV/Vis absorbance for 2 at $500 \mathrm{~nm}$ complicates monitoring of the appearance of the charge transfer band for 7.

However, quenching of fluorescence emission $\left(\lambda_{\max }=370 \mathrm{~nm}\right)$ of the naphthalene unit of 2 within assembly 7 confirms the formation hetero-ternary complex (SI, Figure S50). ${ }^{35}$ Importantly, DOSY NMR (SI, Figure S41) shows that MOP 7 diffuses at same rate $(\mathrm{D}=$ $6.31 \times 10^{-11} \mathrm{~m}^{2} / \mathrm{s}$ ) observed for $\mathbf{5}$. Moreover, we visualized MOP 7 by TEM which revealed both the size and spherical shape of MOPs upon deposition on carbon coated $\mathrm{Cu}$ grids. The particle size was measured to be $5.4 \mathrm{~nm}$ (SI, Figure S57).

As a control experiment we tested the ability of uncapped MOP 3 to bind DOX and its prodrug 2 within the cuboctahedral cavity. DOSY NMR (SI, Figure S43 \& S44) of equimolar mixture of MOP 3 and DOX or MOP 3 and 2 establish that both DOX $(\mathrm{D}=3.55$ $\left.\times 10^{-10} \mathrm{~m}^{2} / \mathrm{s}\right)$ ) and $2\left(\mathrm{D}=3.16 \times 10^{-10} \mathrm{~m}^{2} / \mathrm{s}\right)$ diffuse at much faster rate compared to MOP 3 $\left(\mathrm{D}=6.3 \times 10^{-11} \mathrm{~m}^{2} / \mathrm{s}\right)$. Accordingly, we conclude that neither DOX nor prodrug 2 undergo complexation inside the large cubooctahedral cavity of MOP 3. The combined inference of all these experiments supports the depicted structure of 7 promoted by heteroternary complex formation and further validates the potential of $\mathbf{5}$ as a new drug delivery vehicle.

\section{Stability and Surface Charge of MOPs}

The use of the MOPs in therapeutic or diagnostic applications require high stability under mildly acidic conditions. Accordingly, we verified the stability of MOP 5 from neutral to slightly acidic $\mathrm{pH}$ by TEM and AFM image. Figure 5c shows a TEM image of MOP 5 at pH 5.5 which shows particles of $5.6 \mathrm{~nm}$ diameter which is similar to that observed at neutral $\mathrm{pH}$ (vide supra). Similarly, an AFM image (Figure 5d) of MOP 5 at pH 5.5 shows particles of $5.8 \mathrm{~nm}$ height. We also established the stability of MOP 7 in $10 \mathrm{mM}$ sodium phosphate buffer at $\mathrm{pH} 7.4$ by ${ }^{1} \mathrm{H}$ and DOSY NMR $\left(\mathrm{D}=5.62 \times 10^{-11} \mathrm{~m}^{2} / \mathrm{s}\right.$, Figure $\left.5 \mathrm{a}\right)$. During in vivo studies MOPs will encounter acidic $\mathrm{pH}$ environment only after reaching the tumor site. The excellent stability of MOPs at neutral to slightly acidic $\mathrm{pH}$ and in biologically meaningful 
sodium phosphate buffer (10 mM, pH 7.4) strongly suggests MOPs disintegration during systemic circulation will not occur.

In addition to nanoparticle size, the surface chemistry of nanoparticles plays important role in influencing cellular uptake, ${ }^{39}$ the composition of protein "corona" developing around NPs in $v_{i v o}{ }^{40}$ and their suborgan distributions. ${ }^{22}$ Decreased size and reduced zeta potential $(\zeta)$ increases the circulation time by reducing the interaction with host cells. ${ }^{41}$ MOP 3 is found to be highly cationic $(\zeta=+43 \mathrm{mV})$. However, upon complexation of the MV studs of MOP 3 by $\mathrm{CB}$ [7] or $\mathrm{CB}[8]$ (e.g. 4 and $\mathbf{5}$ ), the $\zeta$ potential decreases significantly. The surface potential $(\zeta)$ of MOP 4 and MOP5 was measured to be $+20.2 \mathrm{mV}$ and $+18.6 \mathrm{mV}$ (Figure $5 b)$. We attribute this decrease in $\zeta$ potential to the shielding of the surface charge by electronegative ureidyl $\mathrm{C}=\mathrm{O}$ portals of $\mathrm{CB}[\mathrm{n}]$. The zeta potential of drug loaded MOP 7 was determined to be $25.0 \mathrm{mV}$, which is slightly larger than MOP 5 presumably due to the presence of cationic prodrug 2 . The excellent stability, nanoscale size, and reduced zeta potential of the $\mathrm{CB}[\mathrm{n}]$ capped MOPs makes them an attractive new candidate for drug delivery applications.

\section{In vitro Cytotoxicity}

A comparative investigation of free $\mathbf{2}$ versus $\mathbf{2}$ formulated as part of nanosphere $\mathbf{7}$ allowed us to assess the influence of the nanosphere on cellular uptake and cytotoxicity. First we incubated 2 or 7 with human cervical cancer cells (HeLa) for $1 \mathrm{~h}$ up to $12 \mathrm{~h}$. Cellular uptake was then measured using flow cytometry (Figure 6a). The mean fluorescence intensity (MFI) of HeLa cells treated with $2(1 \mu \mathrm{M})$ increases from 3.0 to 9.3 -fold dependent on incubation time compared to untreated cells. Under the same conditions, the MFI of cells treated with $7([2]=1 \mu \mathrm{M})$ increases from 5.6 to 16.7-fold compared to untreated cells. Subsequently, the cellular location of drug was evaluated by confocal fluorescence microscopy (Figure 6b). HeLa cells were incubated with $\mathbf{2}$ or $\mathbf{7}$ for $1 \mathrm{~h}$. Confocal fluorescence microscopy images demonstrated red fluorescence of DOX in the nucleus as confirmed by colocalization with the blue fluorescence from the nuclear stain Hoechst 33342. We used the Hoechst 33342 nuclear fluorescence intensity as a reference to quantify nuclear DOX. The ratio of red to blue fluorescence intensity was measured for 15 nuclei per image and mean \pm SEM was calculated as $0.529 \pm 0.03$ and $1.113 \pm 0.100$ for $\mathbf{2}$ and $\mathbf{7}$, respectively (***p $<0.001$, SI, Figure S66). This two-fold higher drug concentration in the nuclei for $\mathbf{7}$ compared to free $\mathbf{2}$ is in agreement with the two-fold better uptake of $\mathbf{7}$ than free 2 measured by flow cytometry.

Finally, we evaluated the cytotoxicity of $\mathbf{2}$ and $\mathbf{7}$ (Figure 6c). We incubated HeLa cells with 7 and separately with $\mathbf{2}$ for $72 \mathrm{~h}$. MTS assays were performed to measure cell viability. Nanosphere 7 displays significantly higher potency $\left(\mathrm{IC}_{50}=48 \pm 8 \mathrm{nM}\right)$ against HeLa cells compared to free prodrug $2\left(\mathrm{IC}_{50}=500 \pm 110 \mathrm{nM}\right)$. In fact, the cytotoxicity of 7 is comparable to free DOX $\left(\mathrm{IC}_{50}=34 \pm 11 \mathrm{nM}\right.$, SI figure S65) but should display in vivo characteristics due to longer circulation time and better tumor uptake via the EPR effect. Importantly, delivery vehicle alone (MOP 5) shows no toxicity against HeLa cells at these concentrations (SI, Figure S64). We conclude that 10-fold higher cytotoxicity of 7 toward 
HeLa cells is due to a combination of better cellular uptake of $\mathbf{7}$ and $\mathrm{pH}$ triggered DOX release from prodrug $\mathbf{2}$ inside HeLa cancer cells.

\section{Conclusion}

In summary, we have reported the design, synthesis and evaluation of metal-organic polyhedron $\mathbf{3}$ as a (pro)drug delivery vehicle. MOP $\mathbf{3}$ is studded with 24 methyl viologen units which enables it to undergo well defined 1:1 host-guest interactions with $\mathrm{CB}$ [7] and $\mathrm{CB}$ [8]. Advantageously, MOP 5 can be loaded with up to 24 molecules of doxorubicin prodrug 2 by $\mathrm{CB}[8]$ promoted hetero ternary charge transfer complex formation. The release of free DOX from 7 occurs by cleavage of the acid sensitive acylhydrazone linkage. MOP 7 is taken up better by HeLa cells than free 2 which results in a 10-fold decrease in the $\mathrm{IC}_{50}$ value to $48 \mathrm{nM}$. Importantly, the cytotoxicity of MOP $7\left(\mathrm{IC}_{50}=48 \mathrm{nM}\right)$ is comparable to free DOX $\left(\mathrm{IC}_{50}=34 \mathrm{nM}\right)$, which shows that the nanoscale architecture of $\mathbf{7}$ imparts improved properties (e.g. uptake) but does not diminish the inherent activity of the drug. Looking forward, we expect that the larger nanoscale architecture of MOP $7(\approx 5-6 \mathrm{~nm})$ and related constructs should benefit from longer circulation times in vivo and potentially reduce side effects due to preferential accumulation in tumors due to the EPR effect. Due to large size and excellent stability in phosphate buffer $\&$ slightly acidic to neutral $\mathrm{pH}$, we believe that the merger between functionalized metal organic polyhedral (MOP) and the recognition properties of $\mathrm{CB}[\mathrm{n}]$ molecular containers enables a wide range of applications by virtue of the plug-and-play nature of the $\mathrm{CB}[8]$ induced hetero ternary complexation. For example, plugging with a multiplicity of prodrugs, fluorophores, PET imaging agents, and targeting ligands is readily envisaged and will enable (multiply) targeted drug delivery, fluorescence or PET imaging for diagnostic and theranostic applications with great potential to improve human health. 5,8

\section{Experimental Section}

\section{General}

Starting materials were purchased from commercial suppliers and were used without further purification. Melting points were measured on a Meltemp apparatus in open capillary tubes and are uncorrected. IR spectra were measured on a Thermo Nicolet NEXUS 670 FT/IR spectrometer by attenuated total reflectance (ATR) and are reported in $\mathrm{cm}^{-1}$. NMR spectra were measured at 400,500 or $600 \mathrm{MHz}$ for ${ }^{1} \mathrm{H}$ and 100 and $125 \mathrm{MHz}$ for ${ }^{13} \mathrm{C}$ using deuterated water $\left(\mathrm{D}_{2} \mathrm{O}\right)$, deuterated chloroform $\left(\mathrm{CDCl}_{3}\right)$, or deuterated dimethyl sulfoxide (DMSO- $d_{6}$ ) as solvent. Chemical shifts $(\delta)$ are referenced relative to the residual resonances for $\mathrm{HOD}(4.79 \mathrm{ppm}), \mathrm{CHCl}_{3}$ (7.26 ppm for ${ }^{1} \mathrm{H}, 77.16 \mathrm{ppm}$ for ${ }^{13} \mathrm{C}$ ), DMSO- $d_{6}(2.50 \mathrm{ppm}$ for ${ }^{1} \mathrm{H}, 39.51 \mathrm{ppm}$ for ${ }^{13} \mathrm{C}$ ). Mass spectrometry was performed using a JEOL AccuTOF electrospray Instrument for routine sample. CSI-MS was performed using Bruker 12T Apex IV FT-ICR-MS at the University of Maryland Baltimore County. Transmission electron microscopy (TEM) was performed on a JEOL JEM 2100. A Digital instruments nanoscope III multimode atomic force microscopy was used for surface characterization. Molecular Modelling (MMFF) was performed using Spartan '08 on a personal computer. 


\section{Compound $\left[1 \cdot 2 \mathrm{NO}_{3}\right]$}

Compound 9 (350 mg, $0.638 \mathrm{mmol})$ and $10(157 \mathrm{mg}, 0.638 \mathrm{mmol})$ were dissolved in DMF (15 mL) completely. Then, 1-ethyl-3-(3-dimethylaminopropyl)carbodiimide (365 mg, 1.91 $\mathrm{mmol})$ and $\mathrm{N}, \mathrm{N}$-dimethylaminopyridine $(77.6 \mathrm{mg}, 0.635 \mathrm{mmol})$ were added to the solution sequentially and stirred at RT for $48 \mathrm{~h}$ under $\mathrm{N}_{2}$. DMF was removed completely under reduced pressure and then diethylether $(15 \mathrm{~mL})$ was added to the crude solid and sonicated for $10 \mathrm{~min}$. The mixture was centrifuged to collect the solid material. The crude solid was then washed with chloroform $(3 \times 15 \mathrm{~mL})$ by sonication and solid was collected by centrifugation. Then solid was washed with hot water $(3 \times 15 \mathrm{~mL})$ using sonication and solid material was collected by centrifugation to afford compound $\left[1 \cdot 2 \mathrm{PF}_{6}\right]$ as a brown solid. The solid was then dried under high vaccum. Then solid material was dissolved completely in acetonitrile $(5 \mathrm{~mL})$. Then a concentrated solution of $(n-\mathrm{Bu})_{4} \mathrm{NO}_{3}(1.0 \mathrm{~g}$ in $1 \mathrm{~mL}$ of acetonitrile) was added to the solution leading to precipitation. The solid was collected by centrifugation and further washed with acetonitrile $(3 \times 5 \mathrm{~mL})$ by sonication. Finally the solid was collected by centrifugation and dried under high vaccum to afford compound $\left[1 \cdot 2 \mathrm{NO}_{3}\right]$ as a grey white solid $(90 \mathrm{mg}, 30 \%)$. M.p. $250-251^{\circ} \mathrm{C}$, IR (ATR, $\left.\mathrm{cm}^{-1}\right) 2920 \mathrm{~m}$, 2850w, 1690s, 1593s, 1546s, 1443m, 1429m, 1407s, 1284w, 1221w, 1141w, 1114s, 1070w, $1029 \mathrm{w}, 994 \mathrm{~m}, 960 \mathrm{w}, 885 \mathrm{~m}, 814 \mathrm{~s}$. 1H NMR (600 MHz, DMSO-d 6 ): $\delta=10.35(\mathrm{~s}, 1 \mathrm{H}), 9.42$ $(\mathrm{d}, J=6.6 \mathrm{~Hz}, 2 \mathrm{H}), 9.23(\mathrm{~d}, J=6.6 \mathrm{~Hz}, 2 \mathrm{H}), 8.79(\mathrm{~d}, J=6.6 \mathrm{~Hz}, 2 \mathrm{H}), 8.69(\mathrm{~d}, J=6.6 \mathrm{~Hz}$, $4 \mathrm{H}), 8.67(\mathrm{~d}, J=6.6 \mathrm{~Hz}, 2 \mathrm{H}), 7.99(\mathrm{~d}, J=1.2 \mathrm{~Hz}, 2 \mathrm{H}), 7.85(\mathrm{~s}, 1 \mathrm{H}), 7.72(\mathrm{~d}, J=6.6 \mathrm{~Hz}, 4 \mathrm{H})$, $4.80(\mathrm{t}, J=6.9 \mathrm{~Hz}, 2 \mathrm{H}), 4.41(\mathrm{~s}, 3 \mathrm{H}), 2.58(\mathrm{t}, J=6.9 \mathrm{~Hz}, 2 \mathrm{H}), 2.38(\mathrm{~m}, J=7.2 \mathrm{~Hz}, 2 \mathrm{H}) .{ }^{13} \mathrm{C}$ NMR (150 MHz, DMSO-d $\left.{ }_{6}\right): \delta=173.4,160.5,150.2,148.7,148.2,146.6,146.5,145.9$, 139.6, 126.5, 126.0, 121.6, 117.8, 113.2, 60.3, 48.0, 30.2, 26.0. MS (ESI, positive) m/z 242 $\left(100 \%,\left[\mathrm{M}-2 \mathrm{NO}_{3}\right]^{2+}\right)$.

Compound 2-Compound $\mathbf{1 3}$ (27.0 mg, $103 \mu \mathrm{mol}$ ) and doxorubicin hydrochloride (20.0 $\mathrm{mg}, 34.5 \mu \mathrm{mol})$ were dissolved in dry $\mathrm{MeOH}(8 \mathrm{~mL})$ under $\mathrm{N}_{2}$. Then trifluoroacetic acid (40 $\mu \mathrm{L}$ ) was added to catalyze the reaction which was protected from light with aluminium foil and stirred for $12 \mathrm{~h}$. Then, the solution was concentrated to a volume of $\sim 1 \mathrm{~mL}$ of volume by rotary evaporation. Dry EtOAc $(2 \mathrm{~mL})$ was added to the solution and sonicated for $5 \mathrm{~min}$. A dark red precipitate was observed. The precipitate was collected by centrifugation. The solid was dried under high vaccum to give 2 as a dark red solid (22 mg, 78\%). M.p. $119-120{ }^{\circ} \mathrm{C}$, IR (ATR, cm ${ }^{-1}$ ) 3190w, 3020w, 2840w, 2638w, 1690s, 1629m, 1600s, 1581m, 1467s, 1389s, 1259s, 1216s, 1180s, 1169s, 1117m, 1029s, 1018s, 985s, 913w, 840s, 814s, 763w, 743s. ${ }^{1} \mathrm{H}$ NMR $\left(600 \mathrm{MHz}\right.$, DMSO- $\left.d_{6}\right) \delta=10.37(\mathrm{~s}, 1 \mathrm{H}), 7.90-7.84(\mathrm{~m}, 2 \mathrm{H}), 7.76$ (brs, 3H), 7.72$7.67(\mathrm{~m}, 3 \mathrm{H}), 7.55(\mathrm{~d}, J=8.4 \mathrm{~Hz}, 1 \mathrm{H}), 7.34$ (t, $J=7.5 \mathrm{~Hz}, 1 \mathrm{H}), 7.23$ (t, $J=7.5 \mathrm{~Hz}, 1 \mathrm{H}), 7.08$ (d, $J=2.4 \mathrm{~Hz}, 1 \mathrm{H}$ ), 6.97 (dd, J = 9.0 Hz, $J=2.4 \mathrm{~Hz}, 1 \mathrm{H}$ ), 5.76 (brs, 1H), 5.44 (brs, 1H), 5.41 (s, 1H), $5.31(\mathrm{~d}, J=3.0 \mathrm{~Hz}, 1 \mathrm{H}), 4.94(\mathrm{t}, J=6.6 \mathrm{~Hz}, 1 \mathrm{H}), 4.43(\mathrm{~m}, 2 \mathrm{H}), 4.06-3.99(\mathrm{~m}, 2 \mathrm{H})$, 3.90 (s, 3H), 3.88 (t, $J=6.0 \mathrm{~Hz}, 2 \mathrm{H}), 3.54(\mathrm{~s}, 1 \mathrm{H}), 3.28$ (d, $J=17.4 \mathrm{~Hz}, 1 \mathrm{H}), 2.76$ (d, $J=$ $17.4 \mathrm{~Hz}, 1 \mathrm{H}), 2.46-2.43(\mathrm{~m}, 2 \mathrm{H}), 2.38-2.32(\mathrm{~m}, 3 \mathrm{H}), 2.17$ (dd, $J=13.5 \mathrm{~Hz}, J=6.3 \mathrm{hz}, 1 \mathrm{H})$, $1.88(\mathrm{td}, J=12.6 \mathrm{~Hz}, J=3.6 \mathrm{~Hz}, 1 \mathrm{H}), 1.71(\mathrm{dd}, J=12.3 \mathrm{~Hz}, J=3.0 \mathrm{~Hz}, 1 \mathrm{H}), 1.59-1.54(\mathrm{~m}$, $4 \mathrm{H}), 4.18-4.16(\mathrm{~m}, 4 \mathrm{H}) .{ }^{13} \mathrm{C}$ NMR $\left(150 \mathrm{MHz}, \mathrm{DMSO}-d_{6}\right) \delta=187.0,186.9,171.9,161.3$, 157.0, 156.5, 154.9, 136.7, 135.7, 135.2, 134.8, 134.6, 129.7, 128.9, 127.9, 127.1, 126.8, $123.9,120.4,120.2,119.5,119.2,111.2,111.1,107.1,99.7,75.2,70.2,67.6,66.6,66.6$, 
64.2, 57.1, 47.0, 36.8, 33.5, 32.5, 28.7, 22.4, 19.0, 17.2. HR-MS: $\mathrm{m} / \mathrm{z} 784.3074$ ([M] ${ }^{+}$, calcd. for $\left.\left[\mathrm{C}_{42} \mathrm{H}_{46} \mathrm{~N}_{3} \mathrm{O}_{12}\right]^{+}, 784.3081\right)$.

$\mathbf{3}=\left[\mathbf{P d}_{\mathbf{1 2}} \mathbf{1}_{\mathbf{2 4}}\right]\left(\mathrm{NO}_{\mathbf{3}}\right)_{\mathbf{7 2}} \mathbf{- 1}(5.50 \mathrm{mg}, 8.99 \mu \mathrm{mol})$ was taken in a 2 -drum vial and $\mathrm{Pd}\left(\mathrm{NO}_{3}\right)_{2} \cdot 2 \mathrm{H}_{2} \mathrm{O}(1.20 \mathrm{mg}, 4.49 \mu \mathrm{mol})$ dissolved in DMSO-d 6 ( $\left.250 \mu \mathrm{L}\right)$ was added.

Additional $250 \mu \mathrm{L}$ of DMSO- $\mathrm{d}_{6}$ was added to the mixture. The reaction mixture was stirred at $60^{\circ} \mathrm{C}$ for $24 \mathrm{~h}$ to afford the $\left[\mathrm{Pd}_{12} \mathbf{1}_{24}\right]\left(\mathrm{NO}_{3}\right)_{72}$ quantitatively as dark brown solution.

$\left[\mathrm{Pd}_{12} \mathbf{1}_{24}\right]\left(\mathrm{NO}_{3}\right)_{72}$ was characterized by ${ }^{1} \mathrm{H}$ NMR, ${ }^{13} \mathrm{CNMR}$, CSI-MS, DOSY. Then solution of $\left[\mathrm{Pd}_{12} \mathbf{1}_{24}\right]\left(\mathrm{NO}_{3}\right)_{72}$ was transferred to a dialysis tube (MWCO 3500$)$ and dialyzed the solution for $24 \mathrm{~h}$ against $\mathrm{D}_{2} \mathrm{O}$ (every $3 \mathrm{~h} \mathrm{D} \mathrm{D}_{2} \mathrm{O}$ was replaced fresh $\mathrm{D}_{2} \mathrm{O}$ ). MP 207-208 ${ }^{\circ} \mathrm{C}$, IR (ATR, $\mathrm{cm}^{-1}$ ) 2962w, 1757s, 1730s, 1640w, 1615w, 1510w, 1391m, 1336m, 1245m, 1222w, $1213 \mathrm{w}, 1183 \mathrm{~m}, 1025 \mathrm{~m}, 1006 \mathrm{~m}, 831 \mathrm{~m}, 760 \mathrm{w} .{ }^{1} \mathrm{H}$ NMR $(600 \mathrm{MHz}$, DMSO-d 6 ) $\delta=10.38$ (s, 24H), 9.42 (brs, 96H), $9.38(\mathrm{~s}, 48 \mathrm{H}), 9.28(\mathrm{~d}, J=6.6 \mathrm{~Hz}, 96 \mathrm{H}), 8.79(\mathrm{~s}, 48 \mathrm{H}), 8.75$ (d, $J=$ $6.6 \mathrm{~Hz}, 48 \mathrm{H}$ ), 8.23 (brs, 168H), 4.75 (brs, 48H), 4.43 (s, 72H), 2.78 (s, 48H), 2.27 (s, 48H). ${ }^{13} \mathrm{C}$ NMR (150 MHz, DMSO-d 6 ) $\delta=173.4,160.7,151.0,149.2,148.7,148.2,146.7$, 145.9, 136.4, 126.5, 126.1, 124.4, 118.3, 114.9, 60.3, 48.0, 30.2, 26.7 ppm. $\left[\operatorname{Pd}_{12} \mathbf{1}_{24}\right]$ $\left(\mathrm{NO}_{3}\right)_{72}$ was treated with excess NaOTf (100 equiv.) in water to afford $\left[\mathrm{Pd}_{12} \mathbf{1}_{24}\right](\mathrm{OTf})_{72}$ and subjected to mass instrument. CSI-Ms (m/z): $\left.1483.5\left[\mathrm{Pd}_{12} \mathbf{1}_{24}\right](\mathrm{OTf})_{57}+10 \mathrm{DMSO}\right]^{15+}$, $\left.\left.1396.5\left[\mathrm{Pd}_{12} \mathbf{1}_{24}\right](\mathrm{OTf})_{56}+13 \mathrm{DMSO}\right]^{16+}, 1311.6\left[\mathrm{Pd}_{12} \mathbf{1}_{24}\right](\mathrm{OTf})_{55}+14 \mathrm{DMSO}\right]^{17+}, 1224.6$ $\left.\left.\left[\mathrm{Pd}_{12} \mathbf{1}_{24}\right](\mathrm{OTf})_{54}+13 \mathrm{DMSO}\right]^{18+}, 1139.6\left[\mathrm{Pd}_{12} \mathbf{1}_{24}\right](\mathrm{OTf})_{53}+10 \mathrm{DMSO}\right]^{19+}, 1052.6$ $\left.\left.\left[\mathrm{Pd}_{12} \mathbf{1}_{24}\right](\mathrm{OTf})_{52}+4 \mathrm{DMSO}\right]^{20+}, 1025.6\left[\mathrm{Pd}_{12} \mathbf{1}_{24}\right](\mathrm{OTf})_{51}+12 \mathrm{DMSO}\right]^{21+}, 967.6\left[\mathrm{Pd}_{12} \mathbf{1}_{24}\right]$ $\left.\left.(\mathrm{OTf})_{50}+11 \mathrm{DMSO}\right]^{22+}, 938.6\left[\mathrm{Pd}_{12} \mathbf{1}_{24}\right](\mathrm{OTf})_{49}+17 \mathrm{DMSO}\right]^{23+}, 880.7\left[\mathrm{Pd}_{12} \mathbf{1}_{24}\right](\mathrm{OTf})_{48}$ $\left.+13 \mathrm{DMSO}]^{24+}, 852.7\left[\mathrm{Pd}_{12} \mathbf{1}_{24}\right](\mathrm{OTf})_{47}+17 \mathrm{DMSO}\right]^{25+}, 795.7\left[\mathrm{Pd}_{12} \mathbf{1}_{24}\right](\mathrm{OTf})_{46}$ $\left.+11 \mathrm{DMSO}]^{26+}, 708.8\left[\mathrm{Pd}_{12} \mathbf{1}_{24}\right](\mathrm{OTf})_{44}+4 \mathrm{DMSO}\right]^{28+}, 681.7\left[\mathrm{Pd}_{12} \mathbf{1}_{24}\right](\mathrm{OTf})_{42}$ $\left.+15 \mathrm{DMSO}]^{30+}, 633.5\left[\mathrm{Pd}_{12} \mathbf{1}_{24}\right](\mathrm{OTf})_{40}+17 \mathrm{DMSO}\right]^{32+}, 580.0\left[\mathrm{Pd}_{12} \mathbf{1}_{24}\right](\mathrm{OTf})_{38}$ $\left.+14 \mathrm{DMSO}]^{34+}, 538.8\left[\mathrm{Pd}_{12} \mathbf{1}_{24}\right](\mathrm{OTf})_{46}+14 \mathrm{DMSO}\right]^{36+}, 509.8\left[\mathrm{Pd}_{12} \mathbf{1}_{24}\right](\mathrm{OTf})_{34}$ $\left.+17 \mathrm{DMSO}]^{38+}, 450.9\left[\mathrm{Pd}_{12} \mathbf{1}_{24}\right](\mathrm{OTf})_{32}+4 \mathrm{DMSO}\right]^{40+}$.

Cell Culture-HeLa cells were grown in Dulbecco's Modified Eagle Medium (DMEM, Gibco Corp) with $10 \%$ feral calf serum (FCS, ATLANTA biologicals) and 1\% penicillin/ streptomycin (Pen/Strep, Gibco Corp) at $37^{\circ} \mathrm{C}$ and $5 \% \mathrm{CO}_{2}$.

Uptake of $\mathbf{2}$ and $\mathbf{7}=\left[\mathrm{Pd}_{\mathbf{1 2}}(\mathbf{1} \cdot \mathrm{CB} \mathbf{2} \cdot \mathbf{2})_{\mathbf{2 4}}\right]\left(\mathrm{NO}_{3}\right)_{\mathbf{7 2}}$-The efficiency of drug delivery of $\mathbf{5}=$ $\left[\mathrm{Pd}_{12}(\mathbf{1} \cdot \mathrm{CB} 8)_{24}\right]\left(\mathrm{NO}_{3}\right)_{72}$ was evaluated by flow cytometry. HeLa cells were plated at $2 \times 10^{5}$ cells/well in 24 wells plate overnight (TPP, Switzerland). Cells were then incubated for 1, 3, 6 or $12 \mathrm{~h}$ with $1 \mu \mathrm{M}$ of $\mathbf{2}$ or $\mathbf{7}$. Untreated cells were used as control. Cells were detached and washed three times with Dulbecco's Phosphate Buffer Saline (DPBS, Gibco Corp). Red fluorescence was analyzed using a 585/42 emission filter of a Canto II flow cytometer (BD bioscience). Results were expressed as the fold of the Mean Fluorescence Intensity (MFI) obtained versus those of untreated cells (equation 1).

$$
\text { Fold MFI untreated }=\mathrm{MFI}_{\text {sample }} / \mathrm{MFI}_{\text {untreated }}
$$


Cytotoxicity of $\mathbf{2}$ and $\mathbf{7}=\left[\mathrm{Pd}_{\mathbf{1 2}}(\mathbf{1} \cdot \mathrm{CB8} \cdot \mathbf{2})_{\mathbf{2 4}}\right]\left(\mathrm{NO}_{3}\right)_{\mathbf{7 2}}$-The cytotoxicity of $\mathbf{2}$ and $\mathbf{7}$ were evaluated using CellTiter 96 aqueous nonradioactive Cell proliferation Assay (Promega Corporation). First, $5 \times 10^{3} \mathrm{HeLa}$ cells/well were plated overnight in a 96 well plate (Corning). Then cells were incubated for $72 \mathrm{~h}$ with a concentration range of $\mathbf{2}$ or $\mathbf{7}$ from $0.0001 \mathrm{uM}$ to $50 \mathrm{uM}$. Cells were washed 3 times with DPBS and then MTS solution was added for $1 \mathrm{~h}$. Absorbance at $490 \mathrm{~nm}$ was measured. Percentage of viable cells was calculated using an untreated group as control using equation 2 :

$$
\text { Cell viability }(\%)=\left(\mathrm{ABS}_{\text {sample }} / \mathrm{ABS}_{\text {untreated }}\right) \times 100
$$

Statistical analysis-Data and error bars for uptake and cytotoxicity studies represent the mean \pm SEM of at least 4 independent experiments. Statistical analyses for comparison between 2 and 7 were carried out using Student's $t$-test. Results with $\mathrm{p}<0.05$ were considered significantly different. Curve fitting of the cytotoxicity data was performed using Graph Pad Prism 6.0. Best nonlinear regression curve-fittings were chosen by evaluating $\mathrm{R}^{2}$, sum of square and the standard deviation of residuals.

Confocal Fluorescence Microscopy-2 $\times 10^{4} \mathrm{HeLa}$ Cells/well were seeded overnight on 24 wells plate containing glass coverslips. Then cells were incubated for $1 \mathrm{~h}$ with $5 \mu \mathrm{M}$ of 2 or 7 and $25 \mu \mathrm{g} / \mathrm{mL}$ of transferring alexa 488 (Molecular Probe, Life Technologies). Cells were washed 3 times in DPBS and fixed for 15 min with $4 \%$ paraformaldehyde. Cells nuclei were stained with Hoechst 33342 for 15 min. Coverslips were mounted on glass slides and observed using a Leica SP5X confocal microscope. Images were acquired using the same parameters for all samples. Quantification of red fluorescence intensity and blue fluorescence intensity were performed using Fiji, scientific image processing application based on ImageJ. Ratio of red fluorescence intensity and blue fluorescence intensity was performed for 15 nuclei per image.

\section{Supplementary Material}

Refer to Web version on PubMed Central for supplementary material.

\section{Acknowledgments}

We thank the National Cancer Institute of the National Institutes of Heath (CA168365) for financial support.

\section{References}

1. Mitragotri S, Burke PA, Langer R. Nat Rev Drug Discovery. 2014; 13:655-672. [PubMed: 25103255]

2. Srinivasarao M, Galliford CV, Low PS. Nat Rev Drug Discovery. 2015; 14:203-219. [PubMed: 25698644]

3. Sengupta S, Eavarone D, Capila I, Zhao G, Watson N, Kiziltepe T, Sasisekharan R. Nature. 2005; 436:568-572. [PubMed: 16049491]

4. Moughton AO, O’Reilly RK. J Am Chem Soc. 2008; 130:8714-8725. [PubMed: 18549205] Wolinsky JB, Grinstaff MW. Adv Drug Deliv Rev. 2008; 60:1037-1055. [PubMed: 18448187]

Ghang YJ, Schramm MP, Zhang F, Acey RA, David CN, Wilson EH, Wang Y, Cheng Q, Hooley RJ. 
J Am Chem Soc. 2013; 135:7090-7093. [PubMed: 23621383] Tian F, Lu Y, Manibusan A, Sellers A, Tran H, Sun Y, Phuong T, Barnett R, Hehli B, Song F, De Guzman MJ, Ensari S, Pinkstaff JK, Sullivan LM, Biroc SL, Cho H, Schultz PG, Di Joseph J, Dougher M, Ma D, Dushin R, Leal M, Tchistiakova L, Feyfant E, Gerber HP, Sapra P. Proc Natl Acad Sci U S A. 2014; 111:1766-1771. [PubMed: 24443552] Zhang F, Zhang S, Pollack SF, Li R, Gonzalez AM, Fan J, Zou J, Leininger SE, Pavia-Sanders A, Johnson R, Nelson LD, Raymond JE, Elsabahy M, Hughes DMP, Lenox MW, Gustafson TP, Wooley KL. J Am Chem Soc. 2015; 137:2056-2066. [PubMed: 25629952] Yu G, Yu W, Shao L, Zhang Z, Chi X, Mao Z, Gao C, Huang F. Adv Funct Mater. 2016; doi: 10.1002/adfm. 201601770Kim CS, Duncan B, Creran B, Rotello VM. Nano Today. 2013; 8:439-447. [PubMed: 24159362] Kierstead PH, Okochi H, Venditto VJ, Chuong TC, Kivimae S, Frechet JMJ, Szoka FC. J Control Release. 2015; 213:1-9. [PubMed: 26093095]

5. Elsabahy M, Heo GS, Lim SM, Sun G, Wooley KL. Chem Rev. 2015; 115:10967-11011. [PubMed: 26463640]

6. Fang J, Nakamura H, Maeda H. Adv Drug Deliv Rev. 2011; 63:136-151. [PubMed: 20441782]

7. Minotti G, Menna P, Salvatorelli E, Cairo G, Gianni L. Pharmacol Rev. 2004; 56:185-229. [PubMed: 15169927]

8. Sun T, Zhang YS, Pang B, Hyun DC, Yang M, Xia Y. Angew Chem, Int Ed. 2014; 53:12320-12364.

9. Zhong YJ, Shao LH, Li YAN. Int J Oncol. 2013; 42:373-383. [PubMed: 23291656] Mitra AK, Agrahari V, Mandal A, Cholkar K, Natarajan C, Shah S, Joseph M, Trinh HM, Vaishya R, Yang X, Hao Y, Khurana V, Pal D. J Control Release. 2015; 219:248-268. [PubMed: 26456750]

10. Etrych T, Jelínková M, Říhová B, Ulbrich K. J Control Release. 2001; 73:89-102. [PubMed: 11337062]

11. Mal P, Breiner B, Rissanen K, Nitschke JR. Science. 2009; 324:1697-1699. [PubMed: 19556504] Tranchemontagne DJ, Mendoza-Cortes JL, O’Keeffe M, Yaghi OM. Chem Soc Rev. 2009; 38:1257-1283. [PubMed: 19384437] Clever GH, Tashiro S, Shionoya M. J Am Chem Soc. 2010; 132:9973-9975. [PubMed: 20604553] Kumari H, Deakyne CA, Atwood JL. Acc Chem Res. 2014; 47:3080-3088. [PubMed: 25198830] Brown CJ, Toste FD, Bergman RG, Raymond KN. Chem Rev. 2015; 115:3012-3035. [PubMed: 25898212] Wang W, Chen LJ, Wang XQ, Sun B, Li X, Zhang Y, Shi J, Yu Y, Zhang L, Liu M, Yang HB. Proc Natl Acad Sci U S A. 2015; 112:55975601. [PubMed: 25902491] Cullen W, Misuraca MC, Hunter CA, Williams NH, Ward MD. Nat Chem. 2016; 8:231-236. [PubMed: 26892554] Wang QQ, Gonell S, Leenders SHAM, Duerr M, Ivanovic-Burmazovic I, Reek JNH. Nat Chem. 2016; 8:225-230. [PubMed: 26892553] Li ZY, Zhang Y, Zhang CW, Chen LJ, Wang C, Tan H, Yu Y, Li X, Yang HB. J Am Chem Soc. 2014; 136:8577-8589. [PubMed: 24571308] Zheng W, Chen LJ, Yang G, Sun B, Wang X, Jiang B, Yin GQ, Zhang L, Li X, Liu M, Chen G, Yang HB. J Am Chem Soc. 2016; 138:4927-4937. [PubMed: 27011050] Young MC, Holloway LR, Johnson AM, Hooley RJ. Angew Chem, Int Ed. 2014; 53:9832-9836.Johnson AM, Wiley CA, Young MC, Zhang X, Lyon Y, Julian RR, Hooley RJ. Angew Chem, Int Ed. 2015; 54:5641-5645.Wang W, Wang YX, Yang HB. Chem Soc Rev. 2016; 45:2656-2693. [PubMed: 27009833] Xu L, Wang Y-X, Chen L-J, Yang H-B. Chem Soc Rev. 2015; 44:2148-2167. [PubMed: 25723131] McConnell AJ, Wood CS, Neelkandan PP, Nitschke JR. Chem Rev. 2015; 115:7729-7793. [PubMed: 25880789]

12. Cook TR, Vajpayee V, Lee MH, Stang PJ, Chi KW. Acc Chem Res. 2013; 46:2464-2474. [PubMed: 23786636]

13. Harris K, Fujita D, Fujita M. Chem Commun. 2013; 49:6703-6712.

14. Zheng YR, Suntharalingam K, Johnstone TC, Lippard SJ. Chem Sci. 2015; 6:1189-1193. [PubMed: 25621144]

15. Yi JW, Barry NPE, Furrer MA, Zava O, Dyson PJ, Therrien B, Kim BH. Bioconjugate Chem. 2012; 23:461-471.

16. He C, Lu K, Liu D, Lin W. J Am Chem Soc. 2014; 136:5181-5184. [PubMed: 24669930]

17. Hotze ACG, Hodges NJ, Hayden RE, Sanchez-Cano C, Paines C, Male N, Tse MK, Bunce CM, Chipman JK, Hannon MJ. Chem Biol. 2008; 15:1258-1267. [PubMed: 19101470] Therrien B, Suess-Fink G, Govindaswamy P, Renfrew AK, Dyson PJ. Angew Chem, Int Ed. 2008; 47:37733776.Vajpayee V, Yang YJ, Kang SC, Kim H, Kim IS, Wang M, Stang PJ, Chi KW. Chem Commun. 2011; 47:5184-5186.Grishagin IV, Pollock JB, Kushal S, Cook TR, Stang PJ, Olenyuk BZ. Proc Natl Acad Sci U S A. 2014; 111:18448-18453. [PubMed: 25516985] 
18. Schmitt F, Freudenreich J, Barry NPE, Juillerat-Jeanneret L, Suss-Fink G, Therrien B. J Am Chem Soc. 2012; 134:754-757. [PubMed: 22185627] Yi JW, Barry NPE, Furrer MA, Zava O, Dyson PJ, Therrien B, Kim BH. Bioconjugate Chem. 2012; 23:461-471.

19. Tominaga M, Suzuki K, Kawano M, Kusukawa T, Ozeki T, Shakamoto S, Yamaguchi K, Fujita M. Angew Chem, Int Ed. 2004; 43:5621-5625.

20. Bruns CJ, Fujita D, Hoshino M, Sato S, Stoddart JF, Fujita M. J Am Chem Soc. 2014; 136:1202712034. [PubMed: 25046565]

21. Kim C, Agasti SS, Zhu Z, Isaacs L, Rotello VM. Nat Chem. 2010; 2:962-966. [PubMed: 20966953] Park KM, Lee DW, Sarkar B, Jung H, Kim J, Ko YH, Lee KE, Jeon H, Kim K. Small. 2010; 6:1430-1441. [PubMed: 20564485] Thomas CR, Ferris DP, Lee JH, Choi E, Cho MH, Kim ES, Stoddart JF, Shin JS, Cheon J, Zink JI. J Am Chem Soc. 2010; 132:10623-10625. [PubMed: 20681678] Li Z, Barnes JC, Bosoy A, Stoddart JF, Zink JI. Chem Soc Rev. 2012; 41:2590-2605. [PubMed: 22216418] Tarn D, Ashley CE, Xue M, Carnes EC, Zink JI, Brinker CJ. Acc Chem Res. 2013; 46:792-801. [PubMed: 23387478]

22. Elci SG, Jiang Y, Yan B, Kim ST, Saha K, Moyano DF, Yesilbag Tonga G, Jackson LC, Rotello VM, Vachet RW. ACS Nano. 2016; 10:5536-5542. [PubMed: 27164169]

23. Wu Z, Song N, Menz R, Pingali B, Yang YW, Zheng Y. Nanomedicine. 2015; 10:1493-1514. [PubMed: 25996121]

24. Nau WM, Florea M, Assaf KI. Isr J Chem. 2011; 51:559-577.Shetty D, Khedkar JK, Park KM, Kim K. Chem Soc Rev. 2015; 44:8747-8761. [PubMed: 26434388] Wu Y, Lan Y, Liu J, Scherman OA. Nanoscale. 2015; 7:13416-13419. [PubMed: 26214063]

25. Masson E, Ling X, Joseph R, Kyeremeh-Mensah L, Lu X. RSC Adv. 2012; 2:1213-1247.

26. Barrow SJ, Kasera S, Rowland MJ, del Barrio J, Scherman OA. Chem Rev. 2015; 115:1232012406. [PubMed: 26566008]

27. Ko YH, Kim E, Hwang I, Kim K. Chem Commun. 2007:1305-1315.

28. Del Barrio J, Horton P, Lairez D, Lloyd G, Toprakcioglu C, Scherman O. J Am Chem Soc. 2013; 135:11760-11763. [PubMed: 23879174] Ghale G, Nau WM. Acc Chem Res. 2014; 47:21502159. [PubMed: 24785659] Benyettou F, Zheng X, Elacqua E, Wang Y, Dalvand P, Asfari Z, Olsen J-C, Han DS, Saleh Ni, Elhabiri M, Weck M, Trabolsi A. Langmuir. 2016; 32:7144-715. [PubMed: 27323835] Benyettou F, Nchimi-Nono K, Jouiad M, Lalatonne Y, Milosevic I, Motte L, Olsen J-C, Saleh Ni, Trabolsi A. Chem - Eur J. 2015; 21:4607-4613. [PubMed: 25582844]

29. Biedermann F, Scherman OA. J Phys Chem B. 2012; 116:2842-2849. [PubMed: 22309573]

30. Bush ME, Bouley ND, Urbach AR. J Am Chem Soc. 2005; 127:14511-14517. [PubMed: 16218648] Heitmann LM, Taylor AB, Hart PJ, Urbach AR. J Am Chem Soc. 2006; 128:1257412581. [PubMed: 16984208]

31. Norouzy A, Azizi Z, Nau WM. Angew Chem, Int Ed. 2015; 54:792-795.

32. Zhang J, Coulston RJ, Jones ST, Geng J, Scherman OA, Abell C. Science. 2012; 335:690-694. [PubMed: 22323815] Smith LC, Leach DG, Blaylock BE, Ali OA, Urbach AR. J Am Chem Soc. 2015; 137:3663-3669. [PubMed: 25710854] Bosmans RPG, Briels JM, Milroy LG, de Greef TFA, Merkx M, Brunsveld L. Angew Chem, Int Ed. 2016; 55:8099-8903.Cavatorta E, Verheijden ML, van Roosmalen W, Voskuhl J, Huskens J, Jonkheijm P. Chem Commun. 2016; 52:7146-7149.Tian J, Chen L, Zhang DW, Liu Y, Li ZT. Chem Commun. 2016; 52:6351-6362.

33. Dong N, Xue SF, Zhu QJ, Tao Z, Zhao Y, Yang LX. Supramol Chem. 2008; 20:659-665.Zhao Y, Buck DP, Morris DL, Pourgholami MH, Day AI, Collins JG. Org Biomol Chem. 2008; 6:4509_ 4515. [PubMed: 19039358] Walker S, Oun R, McInnes FJ, Wheate NJ. Isr J Chem. 2011; 51:616624.Ma D, Zhang B, Hoffmann U, Sundrup MG, Eikermann M, Isaacs L. Angew Chem, Int Ed. 2012; 51:11358-11362.Chen H, Y-W CJ, Li S, Liu JJ, Wyman I, Lee SM-Y, Macartney DH, Wang R. RSC Adv. 2015; 5:63745-63752.

34. Angelos S, Yang YW, Patel K, Stoddart JF, Zink JI. Angew Chem, Int Ed. 2008; 47:22222226.Patel K, Angelos S, Dichtel WR, Coskun A, Yang YW, Zink JI, Stoddart JF. J Am Chem Soc. 2008; 130:2382-2383. [PubMed: 18232687] Meng H, Xue M, Xia T, Zhao YL, Tamanoi F, Stoddart JF, Zink JI, Nel AE. J Am Chem Soc. 2010; 132:12690-12697. [PubMed: 20718462] Thomas CR, Ferris DP, Lee JH, Choi E, Cho MH, Kim ES, Stoddart JF, Shin JS, Cheon J, Zink JI. J Am Chem Soc. 2010; 132:10623-10625. [PubMed: 20681678] Zhao YL, Li Z, Kabehie S, 
Botros YY, Stoddart JF, Zink JI. J Am Chem Soc. 2010; 132:13016-13025. [PubMed: 20799689] Ambrogio MW, Thomas CR, Zhao YL, Zink JI, Stoddart JF. Acc Chem Res. 2011; 44:903-913. [PubMed: 21675720] Yang YW. MedChemComm. 2011; 2:1033-1049.Sun YL, Yang BJ, Zhang SXA, Yang YW. Chem - Eur J. 2012; 18:9212-9216. [PubMed: 22718563] Sun YL, Zhou Y, Li QL, Yang YW. Chem Commun. 2013; 49:9033-9035.Li QL, Sun Y, Sun YL, Wen J, Zhou Y, Bing QM, Isaacs LD, Jin Y, Gao H, Yang YW. Chem Mater. 2014; 26:6418-6431. [PubMed: 25620848] Song N, Yang YW. Chem Soc Rev. 2015; 44:3474-3504. [PubMed: 25904466]

35. Kim HJ, Heo J, Jeon WS, Lee E, Kim J, Sakamoto S, Yamaguchi K, Kim K. Angew Chem, Int Ed. 2001; 40:1526-1529.

36. Ong W, Kaifer AE. J Org Chem. 2004; 69:1383-1385. [PubMed: 14961699]

37. Mizuhara T, Saha K, Moyano DF, Kim CS, Yan B, Kim YK, Rotello VM. Angew Chem, Int Ed. 2015; 54:6567-6570. Yuan YY, Mao CQ, Du XJ, Du JZ, Wang F, Wang J. Adv Mater. 2012; 24:5476-5480. [PubMed: 22886872]

38. Li SY, Liu LH, Rong L, Qiu WX, Jia HZ, Li B, Li F, Zhang XZ. Adv Funct Mater. 2015; $25: 7317$ 7326.

39. Xiao K, Li Y, Luo J, Lee JS, Xiao W, Gonik AM, Agarwal RG, Lam KS. Biomaterials. 2011; 32:3435-3446. [PubMed: 21295849]

40. Fleischer CC, Payne CK. Acc Chem Res. 2014; 47:2651-2659. [PubMed: 25014679]

41. Wang J, Byrne JD, Napier ME, DeSimone JM. Small. 2011; 7:1919-1931. [PubMed: 21695781]

$J$ Am Chem Soc. Author manuscript; available in PMC 2017 November 02. 
a)

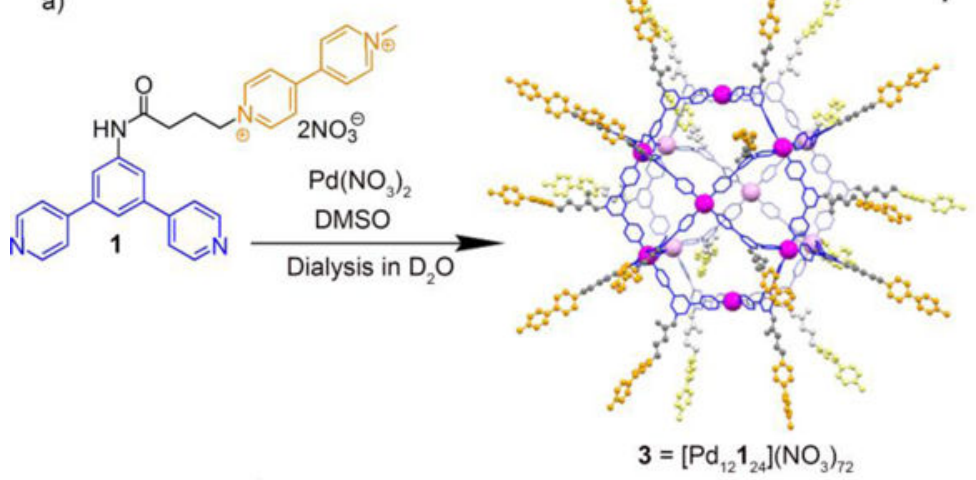

$2^{+}\left(\mathrm{NO}_{3}\right)_{72}$
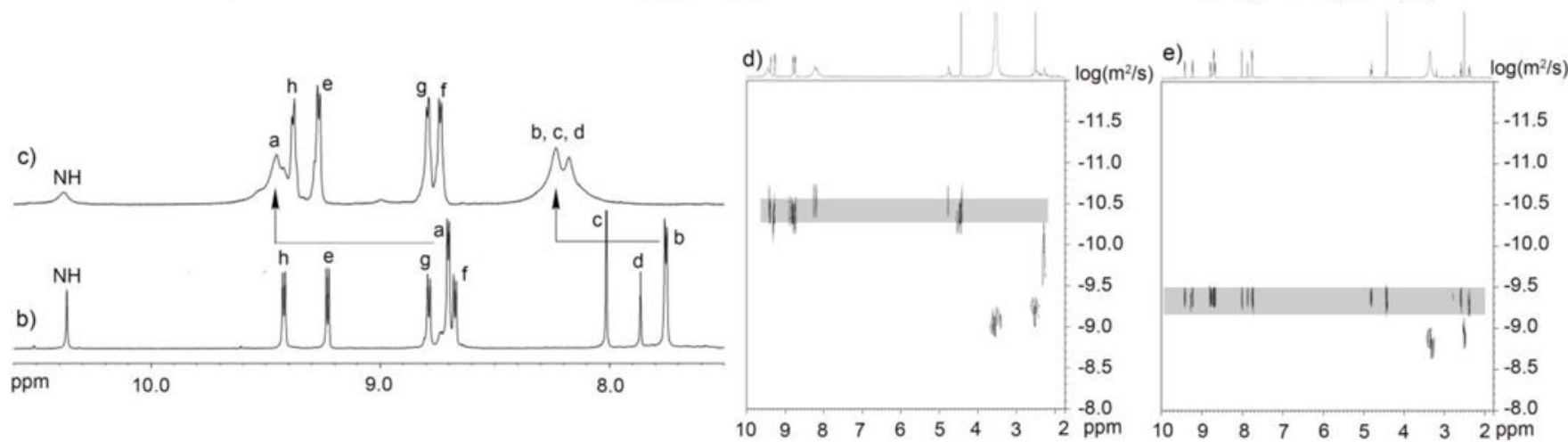

Figure 1.

a) Self-assembly of metal organic polyhedron 3 in DMSO and non-covalent capping with $\mathrm{CB}$ [7] to yield MOP 4 in $\mathrm{D}_{2} \mathrm{O}$. The depicted structures were rendered based on the MMFF minimized structures. ${ }^{1} \mathrm{H}$ NMR spectra recorded $\left(600 \mathrm{MHz}, \mathrm{DMSO}-d_{6}, \mathrm{RT}\right)$ for b) $\mathbf{1}$ and c) 3. $2 \mathrm{D}^{1} \mathrm{H}$ DOSY NMR spectra recorded (600 MHz, DMSO- $d_{6}$, RT) for: d) 3 and e) $\mathbf{1}$. 

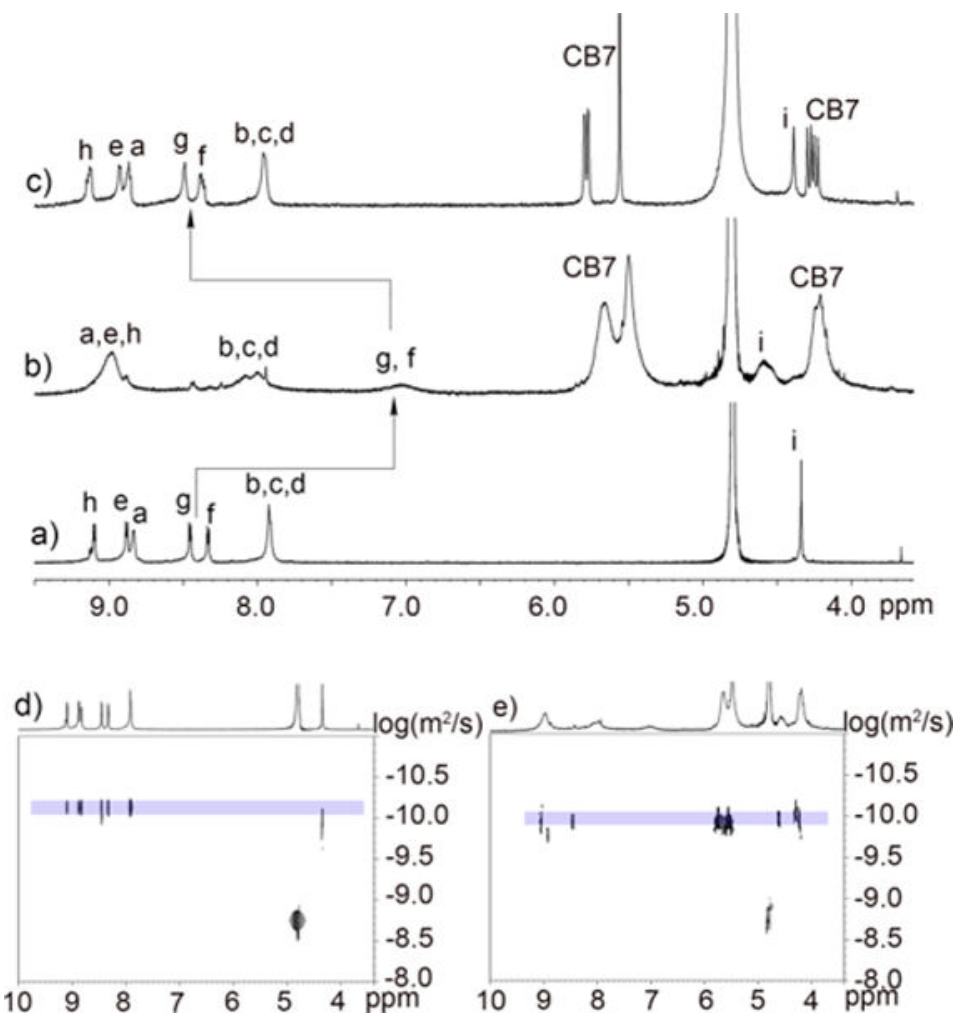

Figure 2.

${ }^{1} \mathrm{H}$ NMR spectra recorded (600 MHz, D2O, RT) for: a) 3, b) 4 and c) 4 with 24 equiv. of ADA. 2D ${ }^{1} \mathrm{H}$ DOSY NMR spectra recorded (600 MHz, D2O, RT) for d) 3, and e) 4. 

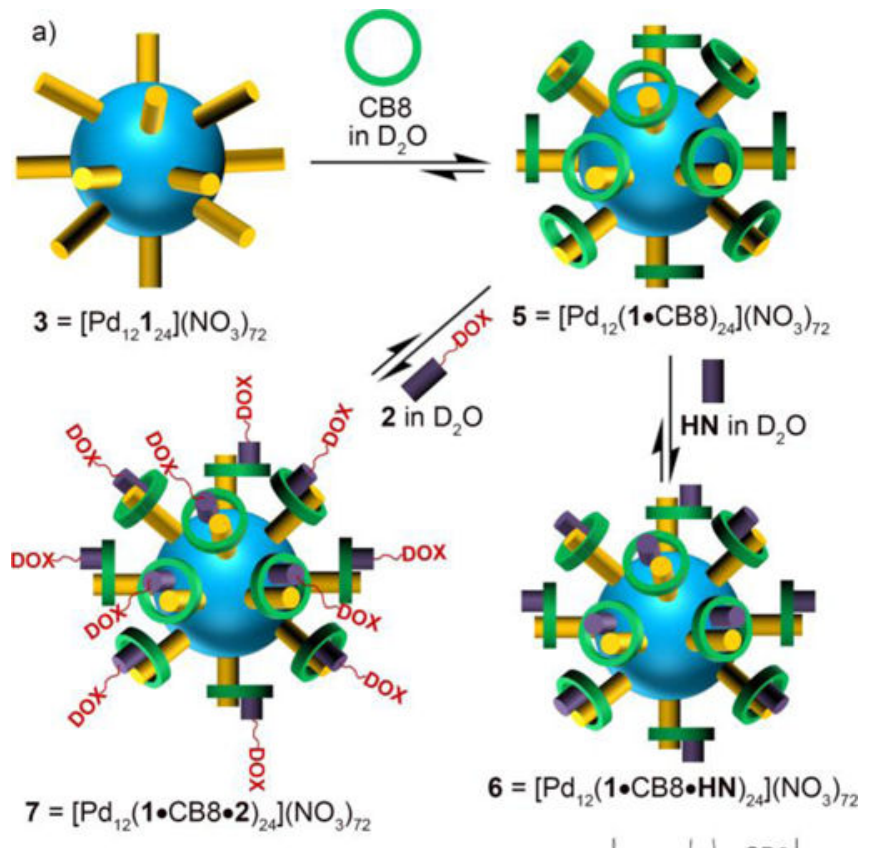

e)
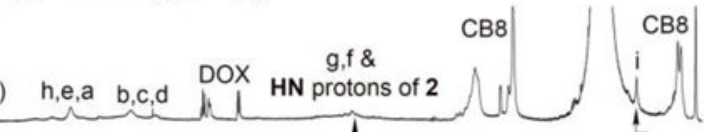

d)
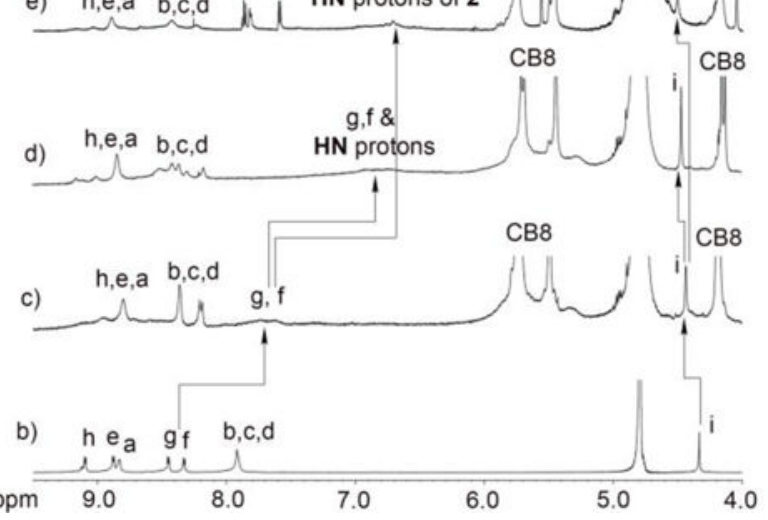

Figure 3.

a) Sequential self-assembly of the methyl viologen units of MOP $\mathbf{3}$ as first guest with CB[8] to yield MOP 5 followed by hetero ternary complex formation with $\mathbf{H N}$ or $\mathbf{2}$ to yield MOP 6 and MOP 7. ${ }^{1} \mathrm{H}$ NMR recorded (600 MHz, $\left.\mathrm{D}_{2} \mathrm{O}, \mathrm{RT}\right)$ for: b) 3, c) 5, d) $\mathbf{6}$, and e) 7. 

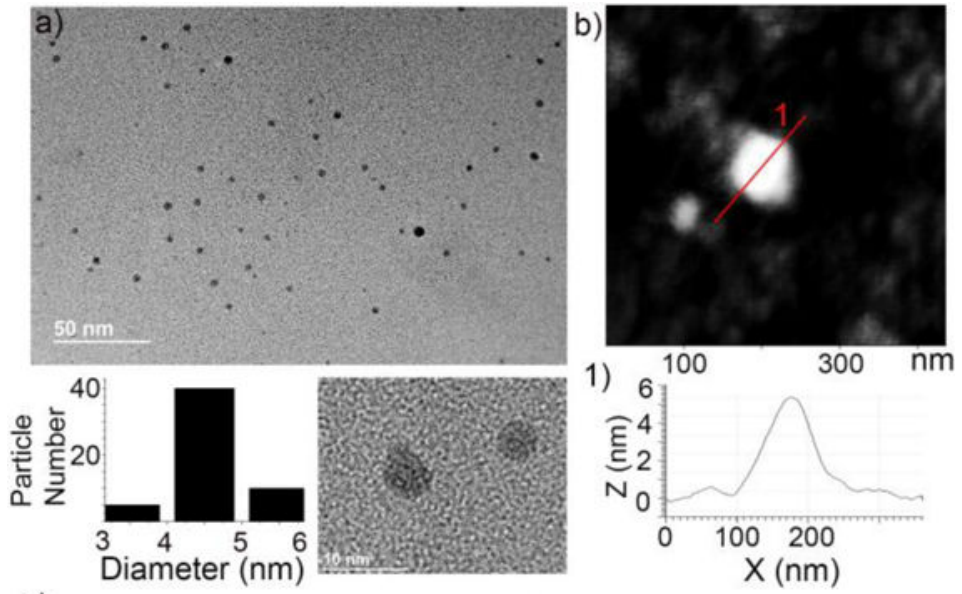

c)
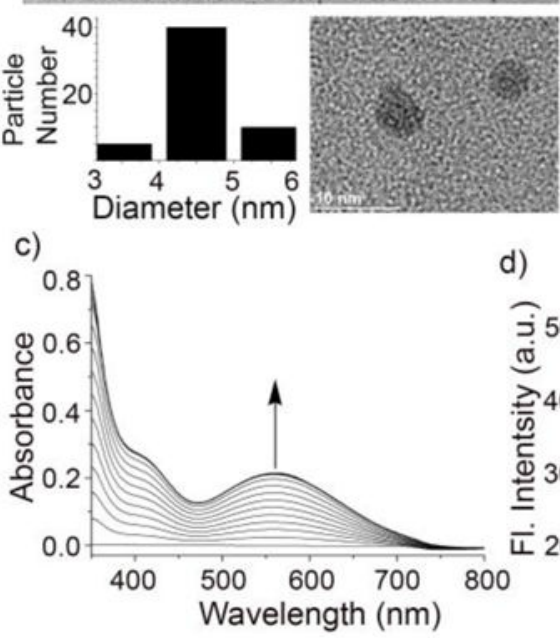

d)

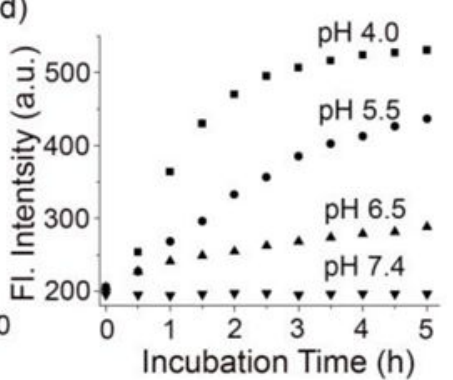

Figure 4.

a) TEM image of $\mathbf{5}$ and the statistical distribution of particle size of $\mathbf{5}$. b) AFM image of $\mathbf{5}$ and its height profile. c) UV-Vis titration of $5(20 \mu \mathrm{M})$ with $\mathbf{H N}(0-500 \mu \mathrm{M})$ in water. d) Plot of change in fluorescence intensity at $\lambda_{\max }=597 \mathrm{~nm}$ versus time after incubating 2 in buffer at $\mathrm{pH} 7.4,6.5,5.5$, and 4.0. 

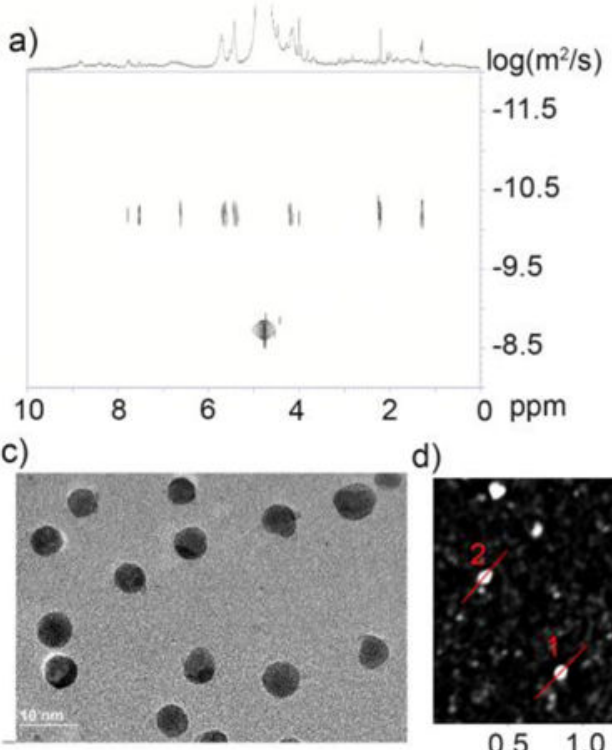

d)

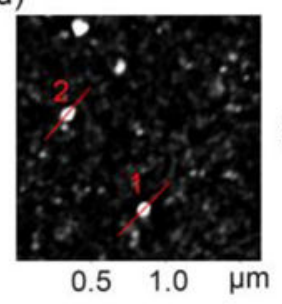

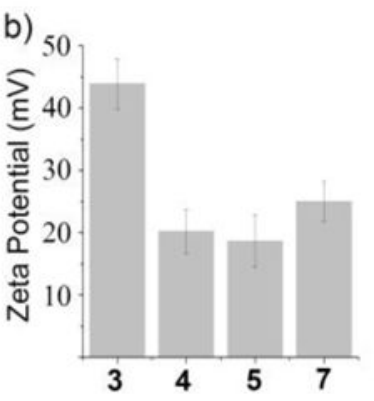

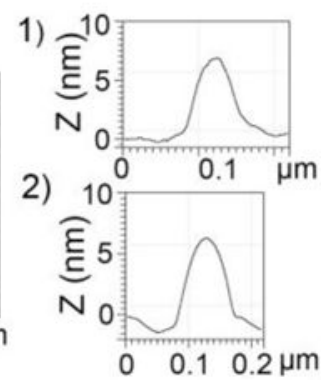

Figure 5.

(a) DOSY NMR of MOP 7 in sodium phosphate buffer $(10 \mathrm{mM})$ at $\mathrm{pH}$ 7.4. (b) Zeta potential of MOP 3, MOP 4, MOP 5 \& MOP 7. (c) TEM image of MOP 5 at pH 5.5. (c) AFM image of MOP 5 at $\mathrm{pH} 5.5$ and its height profile $(1 \& 2)$. 
a)

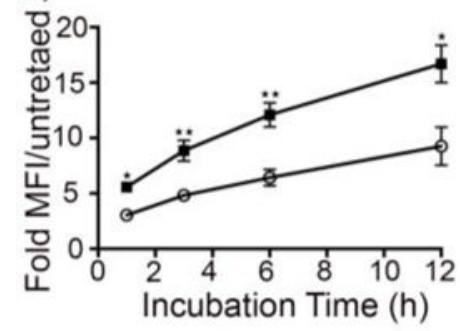

b)
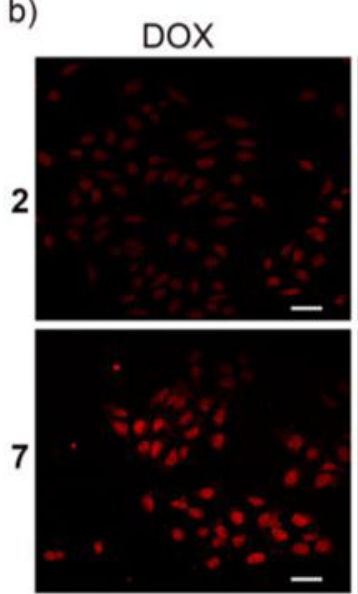

c)

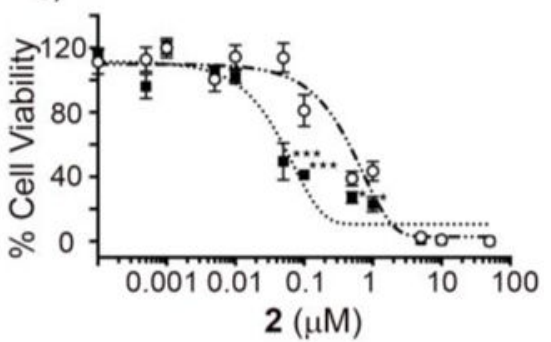

Hoechst
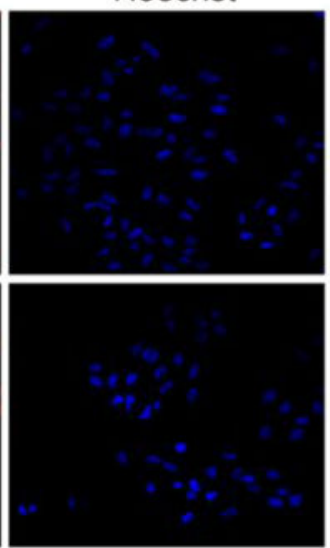

Merge

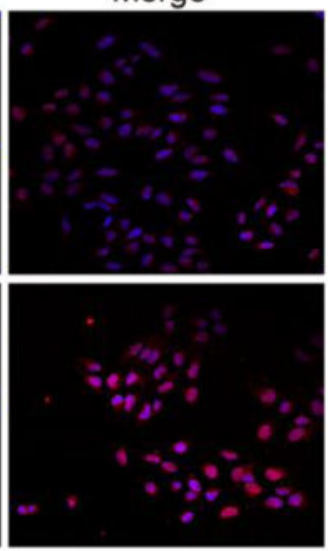

Figure 6.

a) Plot of normalized mean fluorescence intensity (MFI) versus incubation time derived from flow cytometry experiments $(\mathrm{N}=4)$ for HeLa cells treated with $\mathbf{2}(1 \mu \mathrm{M}, \mathrm{o})$ or $\mathbf{7}([\mathbf{2}]=$ $1 \mu \mathrm{M}, \mathbf{\square})$ for $1,3,6$ or $12 \mathrm{~h}$. b) Confocal fluorescence microscopy of HeLa cells treated with $2(5 \mu \mathrm{M})$ or $7([2]=5 \mu \mathrm{M})$ at $40 \times$ magnification. Scale bar $=30 \mu \mathrm{m}$. c) Results of MTS assay for HeLa cells treated with $\mathbf{2}$ (o) or $\mathbf{7}(\mathbf{\square})$. Curve fitting of cytotoxicity data for $\mathbf{2}$ (-•• $-)$ and $7(\bullet \bullet)$ yielded $E C_{50}$ values of $500 \pm 110 \mathrm{nM}$ and $48 \pm 8 \mathrm{nM}$, respectively $(\mathrm{N}=15)$. $* \mathrm{p}<0.05, * * \mathrm{p}<0.01, * * * \mathrm{p}<0.001$. 

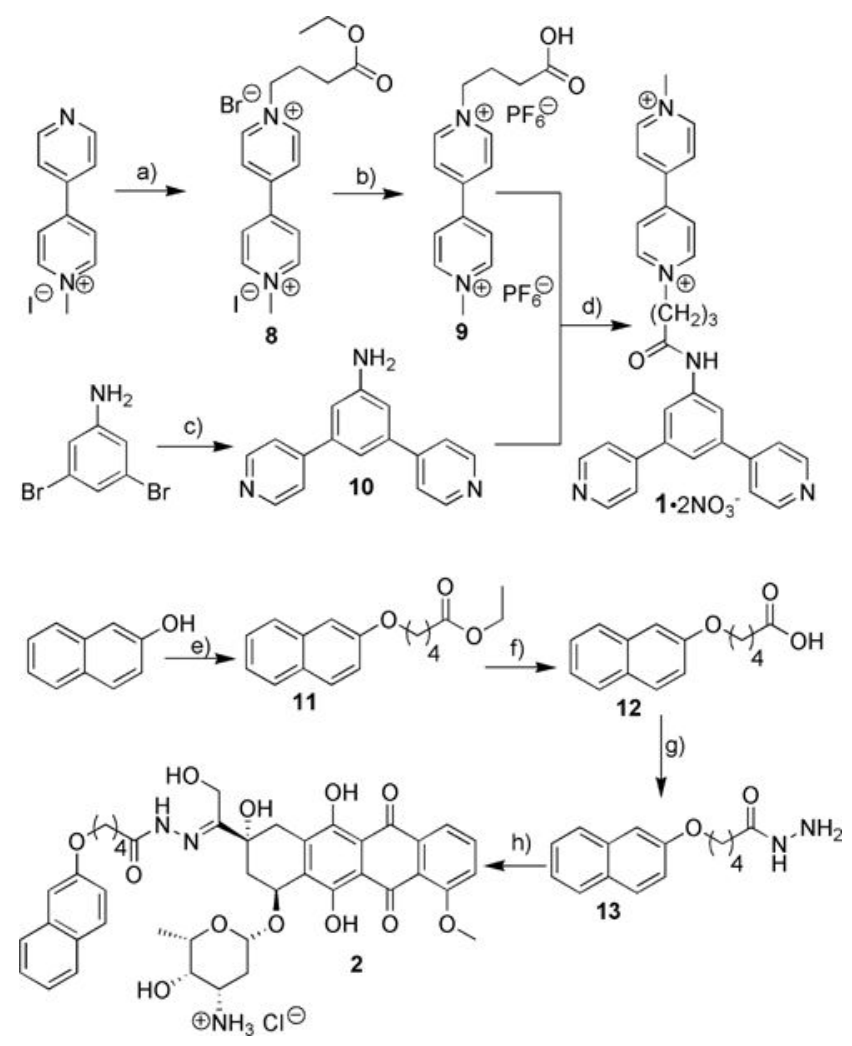

\section{Scheme 1.}

Synthesis of 1 and 2. Conditions: (a) ethyl-4-bromobutyrate, $\mathrm{CH}_{3} \mathrm{CN}, 70{ }^{\circ} \mathrm{C}, 4 \mathrm{~d}, 40 \%$; (b) 2 $\mathrm{M} \mathrm{HBr}, \mathrm{H}_{2} \mathrm{O}, 2 \mathrm{~d}, \mathrm{NH}_{4} \mathrm{PF}_{6}, 80 \%$; (c) $\mathrm{Pd}\left(\mathrm{PPh}_{3}\right)_{4}, \mathrm{~K}_{3} \mathrm{PO}_{4}, \mathrm{H}_{2} \mathrm{O} / 1$, 4 -dioxane $(1: 1), 80{ }^{\circ} \mathrm{C}, 4 \mathrm{~d}$, 72\%; (d) 1-ethyl-3-(3-dimethylaminopropyl)-carbodiimide, DMAP, DMF, $2 \mathrm{~d}$, (n-

$\mathrm{Bu})_{4} \mathrm{NNO}_{3}, \mathrm{CH}_{3} \mathrm{CN}, 30 \%$; e) Ethyl-5-bromovalerate, $\mathrm{K}_{2} \mathrm{CO}_{3}, \mathrm{CH}_{3} \mathrm{CN}, 70{ }^{\circ} \mathrm{C}, 24 \mathrm{~h}, 82 \%$; f) $\mathrm{LiOH}, \mathrm{THF} / \mathrm{H}_{2} \mathrm{O}(1: 1), 70{ }^{\circ} \mathrm{C}, 24 \mathrm{~h}, 1 \mathrm{M} \mathrm{HCl}, 90 \%$; g) 1-ethyl-3-(3-dimethylaminopropyl)carbodiimide, 1-hydroxybenzotriazole, $\mathrm{CH}_{3} \mathrm{CN}, 3 \mathrm{~h}, \mathrm{~N}_{2} \mathrm{H}_{4}$ in $\mathrm{CH}_{3} \mathrm{CN} 0-10{ }^{\circ} \mathrm{C}, 3 \mathrm{~h}, 65 \%$; h) Doxorubicin hydrochloride, trifluoroacetic acid, $\mathrm{MeOH}, 12 \mathrm{~h}$, room temperature, $78 \%$. 

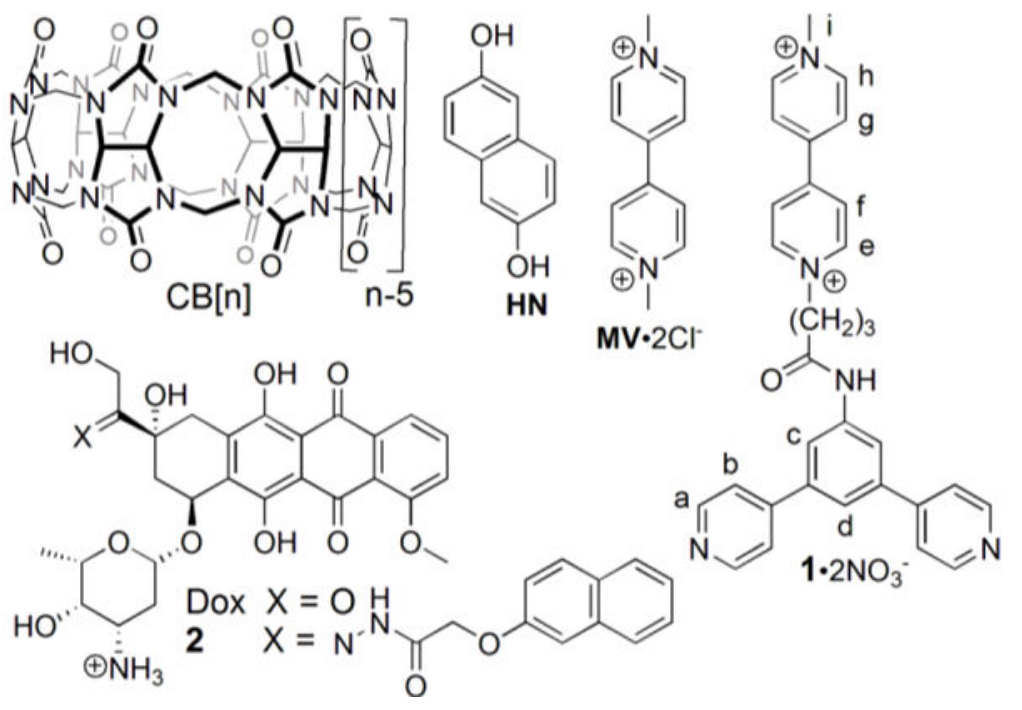

Chart 1.

Chemical structures of compounds used in this study. 